\title{
Quan hệ họ̣p tác Việt Nam - Hoa Kỳ trong lĩnh vụ̣c giáo dục đại học từ năm 1992 đến năm 2015
}

\author{
Hoàng Lê Ngọc Anh \\ Học viện Báo chí và Tuyên truyền \\ E-mail: hoanglengocanh1996@gmail.com
}

Bản hiệu chỉnh

Hà Nội, 16-06-2019 


\title{
HỌC VIỆN BÁO CHÍ VÀ TUYÊN TRUYỀN
}

\author{
HOÀNG LÊ NGỌC ANH
}

QUAN HỆ HỢP TÁC VIẸTT NAM - HOA KỲ

TRONG LĨNH VỰC GIÁO DỤC ĐẠI HỌC

TÙ̀ NĂM 1992 ĐẾN NĂM 2015 


\section{LỜI CAM ĐOAN}

Tôi xin cam đoan khóa luận tốt nghiệp này là công trình nghiên cứu của riêng tôi và chưa từng công bố trước đây dưới bất kỳ hình thức nào. Kiến thức và nội dung được nghiên cứu trong khóa luận là quá trình nghiên cứu, phân tích, tổng hợp lý luận và thực tiễn của cá nhân tôi, không có bất cứ sự sao chép từ các đề tài nghiên cứu khoa học hay khóa luận tốt nghiệp của bất kỳ ai.

Người thực hiện khóa luận

Sinh viên

Hoàng Lê Ngọc Anh 


\section{LỜI CẢM ƠN}

Để hoàn thành khóa luận tốt nghiệp "Quan hệ hợp tác Việt Nam - Hoa Kỳ trong lĩnh vực giáo dục đại học từ năm 1992 đến năm 2015”, đầu tiên, em muốn gửi lời cảm ơn chân thành tới các thầy cô của Học viện Báo chí và Tuyên truyền, các thầy cô được mời về giảng, đặc biệt là các thầy cô trong khoa Quan hệ quốc tế đã tận tình giảng dạy những kiến thức lý luận nền tảng, những kiến thức chuyên ngành cũng như các môn học kĩ năng nghiệp vụ. Nhờ những bài giảng và những chuyến học tập thực tế mà thầy cô tạo cơ hội, em đã tích lũy được cho mình những kiến thức, kĩ năng, kinh nghiệm, là hành trang giúp em chuẩn bị bước vào con đường sự nghiệp sau này.

Em xin dành lời cảm ơn sâu sắc tới cô giáo ThS. Ngô Thị Thúy Hiền vì sự giúp đỡ nhiệt tình khi em thực hiện nghiên cứu khóa luận tốt nghiệp, giúp em định hướng ý tưởng, tổng hợp kiến thức, chỉnh sửa nội dung và cả hình thức trình bày. Cô đã rất tận tâm, đưa ra những nhận xét chi tiết giúp em hoàn thiện khóa luận tốt nghiệp này.

Dù đã có nhiều cố gắng và nỗ lực, song do hạn chế về mặt thời gian cũng như còn hạn chế trong nhận thức của bản thân nên khóa luận không tránh khỏi tồn tại những khuyết điểm, em kính mong nhận được sự chỉ dẫn, đóng góp ý kiến của quý thầy cô để khóa luận hoàn thiện hơn.

Em xin trân trọng cảm ơn!

Sinh viên

Hoàng Lê Ngọc Anh 


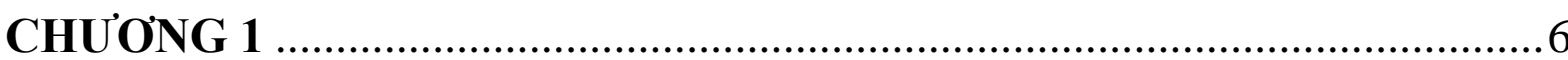

1.1. Khái niệm quan hệ hợp tác Việt Nam - Hoa Kỳ trong lĩnh vực giáo dục đại học

1.2. Một số vấn đề lý luận về quan hệ họ̣p tác Việt Nam - Hoa Kỳ trong lĩnh vực giáo dục đại học

1.3. Một số vấn đề về thực tiễn quan hệ họ̣p tác Việt Nam - Hoa Kỳ trong lĩnh vụ̣c giáo dục đại học ................................................. 17

CHƯONG 2

2.1. Các nhân tố tác động đến quan hệ họ̣p tác Việt Nam - Hoa Kỳ trong lînh vực giáo dục đại học từ năm 1992 đến năm 2015. 20

2.2. Các hình thức hợp tác trong lĩnh vực giáo dục đại học giữa Việt Nam và Hoa Kỳ từ năm 1992 đến năm 2015 21

Bảng 2.1: Các chương trình trao đổi giáo dục của Hoa Kỳ dành cho ........29

Việt Nam (đến tháng 12/2013)

Bảng 2.2: Danh sách các chương trình liên kết đào tạo với Hoa Kỳ đã được Bộ Giáo dục và Đào tạo phê duyệt (2002-2015) 35

Bảng 2.3: Các trường đại học của Việt Nam họ̣p tác với các trường đại học của Hoa Kỳ về áp dụng giảng dạy chương trình tiên tiến ............................ 38

CHƯONG 3

NHẬN XÉT VÀ MỘT SỐ KIẾN NGH! CHO QUAN HỆ HỌP TÁC VIẸTT NAM - HOA KỲ TRONG LĨNH VỤ̉C GIÁO DỤC ĐẠI HỌC

3.1. Nhận xét, đánh giá hiệu quả các hoạt động họ̣p tác Việt Nam - Hoa

Kỳ trong lĩnh vực giáo dục đại học.

Biểu đồ 3.1: Tỉ lệ các chương trình học bổng của Chính phủ Hoa Kỳ dành cho sinh viên Việt Nam (1992-2010).

Bảng 3.1: Số lưọ̣ng sinh viên Việt Nam du học tại Hoa Kỳ (1998-2015) ....45

3.2. Một số kiến nghị góp phần thúc đẩy quan hệ hợp tác Việt Nam - Hoa

Kỳ trong lĩnh vụ̣c giáo dục đại học....................................................51

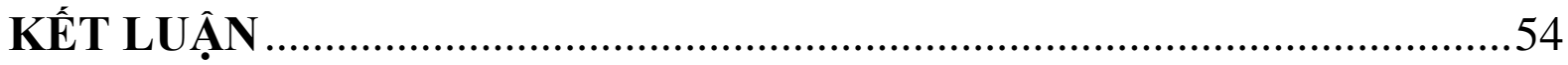

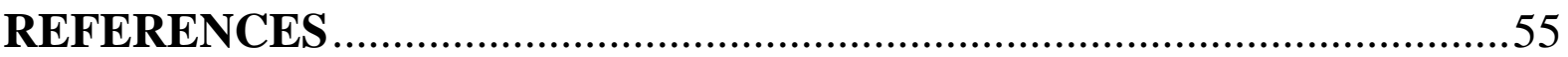




\section{DANH MỤC BẢNG}

Bảng 2.1: Các chương trình trao đổi giáo dục của Hoa Kỳ dành cho ................................29

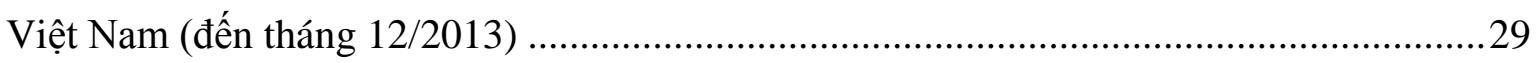

Bảng 2.2: Danh sách các chương trình liên kết đào tạo với Hoa Kỳ đã được Bộ Giáo dục và

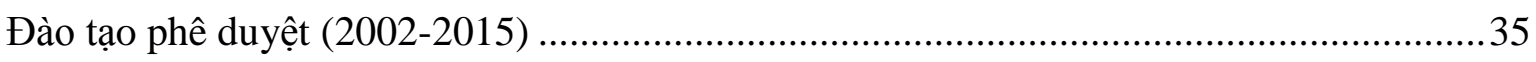

Bảng 2.3: Các trường đại học của Việt Nam hợp tác với các trường đại học của Hoa Kỳ về áp

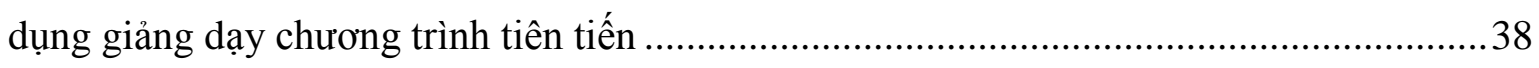

Bảng 3.1: Số lượng sinh viên Việt Nam du học tại Hoa Kỳ (1998-2015)............................ 45

\section{DANH MỤC BIỂU ĐỒ}

Biểu đồ 3.1: Tỉ lệ các chương trình học bổng của Chính phủ Hoa Kỳ dành cho sinh viên Việt Nam (1992-2010)...... .44 


\section{MỞ ĐẦU}

\section{Lý do chọn đề tài}

Trong công tác đối ngoại của Việt Nam, Hoa Kỳ được coi là một đối tác đặc biệt. Từ lịch sử là hai nước cựu thù, tới những khác biệt lớn về thể chế chính trị, văn hóa - xã hội, Việt Nam và Hoa Kỳ đã mất hàng chục năm để thực hiện tiến trình bình thường hóa quan hệ ngoại giao. Cho đến năm 1995, quan hệ song phương giữa hai nước chính thức được bình thường hóa, Việt Nam và Hoa Kỳ tiếp tục phải cố gắng vượt qua những mâu thuẫn để hướng tới mối quan hệ hữu nghị, hợp tác vì lợi ích lâu dài của cả hai - xu thế tất yếu trong bối cảnh toàn cầu hóa ngày càng phát triển. Bên cạnh vấn đề lịch sử giữa hai quốc gia, nếu như Việt Nam coi Hoa Kỳ là đối tác đặc biệt bởi Hoa Kỳ là một nước lớn, có vị thế trên trường quốc tế, có những tác động mạnh mẽ đến quan hệ song phương cũng như đa phương; thì Hoa Kỳ cũng coi Việt Nam là một mối quan tâm đặc biệt bởi vị trí địa chính trị cũng như tiềm năng khai thác của một quốc gia mới nổi, nhất là từ khi chiến lược toàn cầu của Hoa Kỳ đánh giá tầm quan trọng của khu vực Châu Á - Thái Bình Dương (Dong, 2016). Nhìn chung, Việt Nam và Hoa Kỳ đều coi trọng nhau trong chính sách đối ngoại của mình, ngày càng chú trọng xây dựng những chính sách thích hợp cũng như thực hiện nhiều hoạt động hợp tác trên đa dạng các lĩnh vực, đạt được nhiều bước tiến tích cực trong chặng đường hơn 20 năm bình thường hóa quan hệ hai nước.

Hợp tác trên lĩnh vực giáo dục giữa Việt Nam và Hoa Kỳ lần đầu xuất hiện trước cả khi hai nước chính thức bình thường hóa quan hệ. Từ khi bình thường hóa quan hệ, giống như các lĩnh vực kinh tế, quốc phòng - an ninh, văn hóa - xã hội... lĩnh vực giáo dục cũng được chú trọng tăng cường hợp tác, triển khai cụ thể từ chính sách đối ngoại của Việt Nam và Hoa Kỳ. Thậm chí, giáo dục còn được đánh giá là phương tiện chính để hai bên tìm ra đầu mối tiến lên và vượt qua quá khứ (Marklein \& Mai, 2016). Hợp tác giáo dục ngày càng phát triển, tạo ra những bước tiến quan trọng trong quan hệ giữa hai nước.

Sinh viên lựa chọn đề tài nghiên cứu trong lĩnh vực giáo dục đại học trong quan hệ hợp tác giữa Việt Nam - Hoa Kỳ bởi trong bối cảnh toàn cầu hóa, giáo dục đại học trở thành nhu cầu, ưu tiên hàng đầu của nhiều quốc gia đang phát triển, trong đó có Việt Nam. Theo các đánh giá, giáo dục đại học ngày càng đóng vai trò quan trọng, là cốt lõi của sự phát triển trên mọi lĩnh vực chính trị, kinh tế, văn hóa, xã hội của quốc gia. Trong khi đó, giáo dục đại học là sản phẩm ưu thế của các quốc gia phát triển như Hoa Kỳ. Các hoạt động hợp tác, giao lưu giáo dục đại học được coi như một phương thức thực hiện đối ngoại công chúng mà đối tượng tập trung ở đây phần lớn là lứa tuổi thanh thiếu niên, người trưởng thành ở độ tuổi lao động chính trong xã hội, là những người có ảnh hưởng lớn nhất tới sự vận hành của đất nước, 
đồng thời có vai trò quyết định xu hướng phát triển, bao gồm cả việc thúc đẩy quan hệ chính trị, ngoại giao giữa hai quốc gia.

Từ những lý do trên, sinh viên chọn đề tài "Quan hệ hợp tác Việt Nam - Hoa Kỳ trong lĩnh vực giáo dục đại học từ năm 1992 đến năm 2015" nhằm hiểu rõ thực trạng triển khai hợp tác của hai quốc gia trong lĩnh vực giáo dục đại học dựa trên chính sách đối ngoại hai nước đã đề ra, từ đó đưa ra những đánh giá với thực trạng hoạt động này cũng như đóng góp một số ý kiến nhằm hướng đến sự phát triển trong hợp tác giáo dục đại học của Việt Nam với Hoa Kỳ một cách hiệu quả.

\section{Tình hình nghiên cứu đề tài}

Mối quan hệ đặc biệt với nhiều thăng trầm trong lịch sử, từ cựu thù tới phát triển mạnh mẽ toàn diện như Tổng Bí thư Nguyễn Phú Trọng đánh giá: “Chỉ sau 20 năm bình thường hóa quan hệ, hiếm có hai quốc gia nào trên thế giới từ chỗ đối đầu, lại có thể "gác lại quá khứ, vượt qua khác biệt, phát huy tương đồng, hướng tới tương lai” để phát triển quan hệ cả về chất, tầm vóc và chiều sâu như vậy" (Ha, 2016), Việt Nam - Hoa Kỳ đã trở thành đề tài của nhiều tác phẩm, giáo trình, công trình nghiên cứu khoa học, bài báo, tạp chí,... tiêu biểu như "Quan hệ Việt Nam - Hoa Kỳ từ năm 1975 đến nay” của tác giả Nguyễn Ngọc Trung, “Quan hệ chính trị Việt Nam - Hoa Kỳ giai đoạn 1995-2005” của Đoàn Ngọc Tuấn, "Đảng Cộng sản Việt Nam với quan hệ thương mại Việt Nam - Hoa Kỳ (1995 - 2007)” của tác giả Nguyễn Văn Thức, "Vai trò của tổng thống Bill Clinton trong việc hoạch định chính sách đối ngoại với Việt Nam" của tác giả Phạm Thị Thu Hiền, "30 năm quan hệ Việt - Mỹ: Từ cựu thù đến quan hệ đối tác toàn diện" của tác giả Nguyễn Thị Thanh Thủy đăng trên Tạp chí Châu Mỹ số tháng 11/2016. Tuy nhiên các công trình nghiên cứu nổi bật nhất hầu hết tập trung vào mối quan hệ tổng quát giữa Việt Nam và Hoa Kỳ, hoặc nghiên cứu chuyên sâu mối quan hệ này trên lĩnh vực tiêu biểu như hợp tác chính trị, kinh tế, thương mại, quân sự,... Quan hệ hợp tác Việt Nam - Hoa Kỳ trong lĩnh vực giáo dục đại học mới có số ít công trình nghiên cứu khai thác chuyên sâu trực tiếp. Tuy vậy, có thể kể đến một số công trình nghiên cứu đã đề cập đến quan hệ hợp tác Việt Nam - Hoa Kỳ trong lĩnh vực giáo dục đại học:

Cuốn sách "Quá trình bình thường hóa và phát triển quan hệ Việt Nam - Hoa Kỳ (1976-2006) của TS. Nguyễn Anh Cường đã khái quát hai quá trình chính: quá trình bình thường hóa quan hệ Việt Nam - Hoa Kỳ (1976-1995); quá trình phát triển quan hệ Việt Nam - Hoa Kỳ (1996-2006) và từ đó rút ra những nhận xét cũng như kinh nghiệm lịch sử cho quan hệ đối ngoại Việt Nam - Hoa Kỳ. Bên cạnh quá trình tiến tới bình thường hóa quan hệ hết sức lâu dài và phức tạp, tác giả cuốn sách đã tiến hành nghiên cứu quá trình phát triển quan hệ Việt Nam - Hoa Kỳ trong 10 năm sau bình thường hóa, theo chủ trương của Đảng về phát 
triển quan hệ Việt Nam - Hoa Kỳ và đẩy mạnh quan hệ nhiều mặt với Hoa Kỳ. Đề cập đến sự phát triển quan hệ hai nước trên lĩnh vực giáo dục đào tạo, tác giả đã đưa ra dẫn chứng về sự hợp tác, trao đổi giáo dục ngày càng diễn ra sôi nổi (Nguyen A. C., 2015).

Cuốn chuyên khảo "Đối ngoại công chúng: Mô hình hoạt động của một số nước lớn trên thế giới và đề xuất đối với Việt Nam” của tác giả Phạm Minh Sơn tập trung nghiên cứu mô hình hoạt động, kinh nghiệm đối ngoại công chúng của các nước lớn, nhất là hoạt động của các nước này tại Việt Nam, từ đó góp phần đề xuất giải pháp tăng cường hoạt động đối ngoại công chúng nói riêng và công tác đối ngoại của Việt Nam nói chung. Trong nghiên cứu này, các chương trình hợp tác, trao đổi giáo dục được coi như một trong những hình thức hoạt động chủ yếu trong đối ngoại công chúng của Hoa Kỳ, được Hoa Kỳ thực hiện ở nhiều quốc gia trên thế giới, trong đó có Việt Nam. Trong khi đó, Việt Nam cũng là nước "sớm đưa hoạt động đối ngoại công chúng phục vụ quan hệ đối ngoại với Hoa Kỳ”, do đó các hoạt động đối ngoại công chúng nói chung và hợp tác trong lĩnh vực giáo dục giữa quan hệ hai nước nói riêng sớm được tiến hành từ những năm 90 của thế kỷ $\mathrm{XX}$, và ngày càng có sự tiến bộ đặc biệt từ sau khi hai nước bình thường hóa quan hệ ngoại giao vào năm 1995 (Pham, 2016). Như vậy, cuốn chuyên khảo tập trung nghiên cứu các mô hình đối ngoại công chúng của một số nước lớn trên thế giới, sự hợp tác trong lĩnh vực giáo dục giữa Việt Nam và Hoa Kỳ đã được đề cập đến trong mô hình hoạt động đối ngoại công chúng của Hoa Kỳ - một nước lớn và tác động tới Việt Nam, tuy có thông tin về hoạt động hợp tác giáo dục như các chương trình trao đổi, số lượng du học sinh cập nhật đến những năm 2015, nhưng quan hệ hợp tác Việt Nam - Hoa Kỳ trong lĩnh vực giáo dục đại học chưa phải là đối tượng được đi sâu nghiên cứu trong công trình này.

Một trong số ít những công trình tập trung nghiên cứu quan hệ hợp tác Việt Nam Hoa Kỳ trong lĩnh vực giáo dục đại học có thể kể đến luận văn Thạc sĩ "Quan hệ Việt Nam Hoa Kỳ trên lĩnh vực văn hóa, giáo dục và xã hội từ năm 1995 đến nay” của tác giả Nguyễn Bích Thảo, Đại học Khoa học Xã hội và Nhân văn, cho rằng ngoài những yếu tố chính trị trong chính sách đối ngoại của Việt Nam và Hoa Kỳ, việc tăng cường trao đổi và hợp tác giáo dục giữa hai quốc gia cũng là một cách để hai nước tăng cường tình hữu nghị, hợp tác nhằm hóa giải những hiểu lầm trong quá khứ, giúp hai nước ngày càng có sự hợp tác nhiều hơn trong tương lai. Ở mức độ nhất định, sự giúp đỡ của Hoa Kỳ trong việc đào tạo nguồn nhân lực cho Việt Nam sẽ là một yếu tố tạo thành công cho cả Việt Nam và Hoa Kỳ (Nguyen $B$. T., 2010). Tác giả nghiên cứu các hình thức hợp tác giáo dục giữa hai nước, bao gồm các chương trình trao đổi giáo dục giữa chính phủ, thông qua các tổ chức phi chính phủ và hợp tác giữa các trường đại học, nhìn chung bao quát được tình hình quan hệ hợp tác Việt Nam - 
Hoa Kỳ trên lĩnh vực giáo dục từ năm 1995 đến thời điểm hoàn thành công trình nghiên cứu (năm 2010). Tuy nhiên theo đối tượng nghiên cứu trên cả lĩnh vực văn hóa, giáo dục, xã hội, tác giả không lựa chọn đi sâu vào lĩnh vực giáo dục đại học, cũng như phân tích chính sách của hai nước, đánh giá hiệu quả, hạn chế đối với riêng lĩnh vực hợp tác này.

Bên cạnh đó, bài báo khoa học "Hợp tác giáo dục đại học giữa Việt Nam và Hoa Kỳ từ đầu thập niên 1990 đến nay" của PGS, TS Nguyễn Thị Thanh Thủy đăng trên Tạp chí Châu Mỹ ngày nay số 07-2015 đã phân tích các yếu tố tác động đến sự hợp tác về lĩnh vực giáo dục đại học giữa hai nước, tập trung nghiên cứu các hình thức hợp tác và thực trạng trong thời gian từ đầu thập niên 1990 đến năm 2015, từ đó đưa ra một số nhận xét và kiến nghị nhằm tăng cường sự hợp tác này cũng như mối quan hệ đối tác toàn diện giữa Việt Nam - Hoa Kỳ.

\section{Mục đích, nhiệm vụ nghiên cứu}

\subsection{Mục đích nghiên cứu}

Nghiên cứu về quan hệ hợp tác Việt Nam - Hoa Kỳ trong lĩnh vực giáo dục đại học nhằm nắm được thực trạng quan hệ hai nước trong lĩnh vực giáo dục đại học, tìm hiểu những thành công, hạn chế trong việc triển khai hoạt động đối ngoại công chúng thông qua giáo dục đại học, từ đó rút ra những bài học kinh nghiệm và đề xuất góp phần thúc đẩy quan hệ hai nước trong lĩnh vực giáo dục đại học.

\subsection{Nhiệm vụ nghiên cúu}

Để đạt được mục đích nghiên cứu, sinh viên cần thực hiện những nhiệm vụ nghiên cứu cụ thể:

Làm rõ những vấn đề liên quan đến chính sách đối ngoại của Việt Nam, Hoa Kỳ trong hợp tác giáo dục đại học giữa hai nước;

Nghiên cứu các nhân tố tác động và thực trạng hợp tác giáo dục đại học của hai nước;

Từ thực trạng đó rút ra nhận xét, đánh giá về hiệu quả hoạt động hợp tác Việt Nam Hoa Kỳ trong lĩnh vực giáo dục đại học và đưa ra một số kiến nghị góp phần thúc đẩy quan hệ hai nước trong lĩnh vực giáo dục đại học.

\section{4. Đối tượng, phạm vi nghiên cứu}

4.1. Đối tượng nghiên cứu: Quan hệ hợp tác Việt Nam - Hoa Kỳ trong lĩnh vực giáo dục đại học

4.2. Phạm vi nghiên cứu: Hợp tác Việt Nam - Hoa Kỳ trong lĩnh vực giáo dục bậc đại học trong giai đoạn từ năm 1992 khi bắt đầu xuất hiện hình thức hợp tác giáo dục đầu tiên giữa hai nước, trước cả khi hai nước bình thường hóa quan hệ ngoại giao, đến năm 2015 là thời điểm 20 năm sau khi hai nước chính thức bình thường hóa quan hệ và đạt được những 
thành tựu nổi bật trong hợp tác giáo dục đại học. Do giới hạn của khóa luận tốt nghiệp cũng như nguồn lực để khảo sát, dánh giá nên phạm vi không gia nghiên cứu là những hoạt động hợp tác giáo dục diễn ra tại Việt Nam.

\section{Cơ sở lý luận và phương pháp nghiên cứu}

\subsection{Cơ sở lý luận}

Trên cơ sở phương pháp luận chủ nghĩa duy vật biện chứng của Mác - Lênin, tư tưởng Hồ Chí Minh và chính sách của Đảng nhà nước Việt Nam, chính sách đối ngoại của Hoa Kỳ về đối ngoại nói chung, về đối ngoại công chúng trên lĩnh vực giáo dục nói riêng.

\subsection{Phương pháp nghiên cứu}

Đề tài sử dụng các phương pháp nghiên cứu chủ yếu:

Phương pháp nghiên cứu lịch sử để nghiên cứu quan hệ ngoại giao Việt Nam, Hoa Kỳ qua thời gian, đặc biệt trong hợp tác giáo dục đại học.

Phương pháp tổng hợp, phân tích những tài liệu thu thập được một cách chọn lọc từ chính sách của Việt Nam và Hoa Kỳ, cũng như từ các công trình nghiên cứu, tin tức cập nhật về quan hệ hợp tác giữa Việt Nam và Hoa Kỳ trong lĩnh vực hợp tác giáo dục đại học.

\section{6. Ý nghĩa lý luận, thực tiễn}

Kết quả đề tài nghiên cứu sẽ góp phần vào việc nghiên cứu, tổng hợp những điểm cơ bản trong chính sách của Việt Nam và Hoa Kỳ đối với hoạt động hợp tác giáo dục đại học giữa hai nước, nằm trong chính sách đối ngoại, đặc biệt là đối ngoại công chúng của hai nước. Đồng thời tác giả tổng hợp, phân tích thực trạng các hình thức hợp tác trong lĩnh vực giáo dục đại học giữa Việt Nam và Hoa Kỳ từ năm 1992 đến nay, những thành tựu đạt được và hạn chế trong hoạt động hợp tác đó, từ đó đưa ra một số kiến nghị góp phần tăng cường hiệu quả hợp tác giáo dục đại học cho Việt Nam. Kết quả nghiên cứu đề tài có thể trở thành tài liệu tham khảo cho các sinh viên khóa sau khi nghiên cứu về quan hệ đối ngoại Việt Nam - Hoa Kỳ, đặc biệt trong quan hệ hợp tác giáo dục đại học, hay quan hệ đối ngoại công chúng của hai quốc gia.

\section{Kết cấu đề tài}

Ngoài các mục mở đầu, kết luận, danh mục tài liệu tham khảo, mục lục, khóa luận được kết cấu gồm ba chương:

Chương 1: Những vấn đề lý luận và thực tiễn về quan hệ họ̣p tác Việt Nam Hoa Kỳ trong lĩnh vực giáo dục đại học

Làm rõ khái niệm liên quan đến quan hệ hợp tác Việt Nam - Hoa Kỳ trong lĩnh vực giáo dục đại; nêu ra và phân tích các vấn đề lý luận và thực tiễn về quan hệ hợp tác trong lĩnh vực giáo dục đại học giữa Việt Nam và Hoa Kỳ. 


\section{Chương 2: Thực trạng quan hệ hợp tác Việt Nam - Hoa Kỳ trong lĩnh vực giáo} dục đại học từ năm 1992 đến năm 2015

Phân tích nhân tố tác động đến quan hệ hợp tác giáo dục đại học giữa Việt Nam và Hoa Kỳ; Khái quát các hình thức hợp tác giữa Việt Nam - Hoa Kỳ trong lĩnh vực giáo dục đại học từ năm 1992 đến năm 2015 bao gồm phân tích hoạt động của các chương trình trao đổi giáo dục đại học, Nhóm Chuyên trách hợp tác giáo dục Việt Nam - Hoa Kỳ và hợp tác trong xây dựng mô hình giáo dục đại học ở Việt Nam.

Chương 3: Nhận xét và một số kiến nghị cho quan hệ hợp tác Việt Nam - Hoa Kỳ trong lĩnh vụ̣c giáo dục đại học

Nhận xét, đánh giá hiệu quả các hoạt động hợp tác Việt Nam - Hoa Kỳ trong lĩnh vực giáo dục đại học và từ đó nêu một số kiến nghị góp phần thúc đẩy quan hệ hợp tác Việt Nam - Hoa Kỳ trong lĩnh vực giáo dục đại học.

\section{CHƯONG 1}

\section{NHŨ̉NG VẤN ĐỀ LÝ LUẬN VÀ THỤ̉C TIẼ̃N VỀ QUAN HỆ HỘP TÁC VIỆT NAM - HOA KỲ TRONG LĨNH VỤ̉C GIÁO DỤC ĐẠI HỌC}

\footnotetext{
1.1. Khái niệm quan hệ hợp tác Việt Nam - Hoa Kỳ trong lĩnh vực giáo dục đại học

Về ngữ nghĩa, “quan hệ” được hiểu là những hành vi có tác động trực tiếp hoặc gián tiếp lên đối tượng khác. Phải có hai chủ thể quan hệ trở lên thì mới có quan hệ, tức là phải có chủ thể gây tác động và chủ thể bị tác động thì tác động đó mới trở thành quan hệ (Hoang, 2016), và tác động qua lại xảy ra giữa các chủ thể là các quốc gia khác nhau thì quan hệ đó được coi là quan hệ quốc tế. Khái niệm về quan hệ quốc tế lần đầu tiên xuất hiện vào thế kỷ XVIII là "sự giao tiếp giữa các quốc gia". Tuy nhiên sự phát triển về quy mô, mức độ, đa dạng các chủ thể tham gia cũng như các lĩnh vực, vấn đề... Chủ thể quan hệ quốc tế không chỉ còn là các chủ thể quốc gia mà còn các chủ thể phi quốc gia, các phương thức quan hệ phát triển theo cả chiều rộng và chiều sâu, mở rộng quy mô quan hệ và mức độ chiều sâu của các
} 
mối quan hệ đó. Nếu như trước đây quan hệ quốc tế chủ yếu trên lĩnh vực chính trị thì càng ngày càng đa dạng các lĩnh vực khác tham gia vào đời sống quan hệ quốc tế như kinh tế, quân sự, văn hóa, xã hội,... Do vậy, khái niệm quan hệ quốc tế đã được mở rộng hơn so với khái niệm ban đầu để phù hợp với thực tiễn tình hình các quan hệ diễn ra giữa các chủ thể quốc tế, có thể hiểu một cách bao quát: Quan hệ quốc tế là sự tương tác qua biên giới giữa các chủ thể quan hệ quốc tế (Hoang, 2016).

Trong quan hệ quốc tế, hợp tác được coi là một trong những hình thức quan hệ cơ bản nhất. Theo từ điển tiếng Việt, "hợp tác" nghĩa là chung sức, cùng nhau làm việc gì đó để cùng đạt được mục đích. Hợp tác đã xuất hiện từ thời kỳ đầu của loài người khi người và người hợp tác với nhau để hình thành các cộng đồng sơ khai nhất. Cho đến khi quốc gia và dân tộc hình thành, tức là xuất hiện chủ thể quan hệ quốc tế, hợp tác giữa chúng đã trở thành hợp tác quốc tế. Cho đến nay, hợp tác quốc tế đã trở thành xu thế lớn trong quan hệ quốc tế, lôi cuốn mọi quốc gia và con người khắp nơi trên cùng thế giới cùng tham gia (Hoang, 2016).

Như vậy, khái niệm chung về hợp tác quốc tế có thể hiểu là sự phối hợp hòa bình giữa các chủ thể quan hệ quốc tế nhằm thực hiện các mục đích chung và phân loại hợp tác quốc tế theo ba cách phân loại chính: dựa trên lĩnh vực hoạt động, bao gồm cả các lĩnh vực lớn và phân loại chi tiết; căn cứ trên số lượng chủ thể tham gia, có thể phân loại hợp tác quốc tế thành song phương và đa phương; và dựa theo quy mô không gian để phân loại thành hợp tác khu vực và hợp tác toàn cầu (Hoang, 2016). Dựa theo những cách phân loại này, có thể thấy đối tượng nghiên cứu của đề tài - quan hệ hợp tác Việt Nam - Hoa Kỳ trong lĩnh vực giáo dục đại học - là kiểu hợp tác song phương và chọn lĩnh vực hợp tác cụ thể là giáo dục đại học.

Khái niệm "giáo dục đại học" được hiểu theo nhiều nghĩa khác nhau. Sự đa dạng về quan điểm là khó tránh khỏi, và nhiều người cho rằng đó là điều cần thiết (Mishra, 2007).

Theo Barnett (1992), có 4 khái niệm thông dụng nhất về giáo dục đại học:

i) Giáo dục đại học là một dây chuyền sản xuất mà đầu ra là nguồn nhân lực đạt chuẩn. Theo quan điểm này, giáo dục đại học là một quá trình trong đó người học được quan niệm như những sản phẩm được cung ứng cho thị trường lao động. Như vậy, giáo dục đại học trở thành “đầu vào" tạo nên sự phát triển và tăng trưởng của thương mại và công nghiệp.

ii) Giáo dục đại học là đào tạo để trở thành nhà nghiên cứu. Theo cách nhìn này, giáo dục đại học là thời gian chuẩn bị để tạo ra những nhà khoa học và nhà nghiên cứu thực thụ, những người sẽ không ngừng tìm những chân trời kiến thức mới. Chất lượng ở đây hướng về việc tạo ra các công bố khoa học và tinh thần làm việc nghiêm nhặt để thực hiện các nghiên cứu có chất lượng. 
iii) Giáo dục đại học là quản lý việc tổ chức giảng dạy một cách hiệu quả. Rất nhiều người cho rằng giảng dạy là hoạt động cốt lõi của một cơ sở giáo dục. Do vậy, các cơ sở giáo dục đại học thường chú trọng quản lý một cách hiệu quả các hoạt động dạy và học bằng cách nâng cao chất lượng giảng dạy và nâng cao tỷ lệ kết thúc khóa học của sinh viên.

iv) Giáo dục đại học là mở rộng cơ hội trong cuộc sống cho người học. Theo cách tiếp cận này, giáo dục đại học được xem như một cơ hội để người học được tham gia vào quá trình phát triển bản thân bằng các thể thức học tập thường xuyên và linh hoạt.

Tuy vậy trong 4 khái niệm trên, không có khái niệm duy nhất chính xác nhất về giáo dục đại học, mà 4 khái niệm đó mang tính bổ trợ cho nhau, tạo ra một bức tranh toàn cảnh để hiểu về giáo dục đại học. Nhìn vào các hoạt động của các cơ sở đào tạo giáo dục đại học, có thể thấy "giảng dạy, nghiên cứu và chuyển giao ứng dụng là các chức năng chính của giáo dục đại học" (Barnett, 1992).

Theo Rhodes (2001), giáo dục đại học "là giai đoạn giáo dục thường diễn ra ở các trường đại học, viện đại học, đại học, trường cao đẳng, học viện, và viện công nghệ."

Hay theo định nghĩa trong Từ điển Bách khoa toàn thư Việt Nam, giáo dục đại học “bao gồm các bậc sau trung học như cao đẳng, đại học và sau đại học”. Tương tự, Đoàn Văn Dũng (2015) cho rằng ở Việt Nam hiện nay chưa có định nghĩa chính thức về giáo dục đại học, nhưng có thể hiểu giáo dục đại học là hình thức tổ chức giáo dục cho các bậc học sau giai đoạn bậc phổ thông với các trình độ đào tạo: gồm trình độ cao đẳng, trình độ đại học, trình độ thạc sĩ và trình độ tiến sĩ (Doan, 2015).

Tổng hợp quan điểm và thực tiễn của giáo dục đại học trên thế giới, UNESCO đưa ra khái niệm về giáo dục đại học trong bản "Tuyên ngôn thế giới về giáo dục Đại học cho thế kỷ XXI tầm nhìn và hành động” của UNESCO được ký bởi 182 quốc gia thành viên trong đó có Hoa Kỳ và Việt Nam, giáo dục đại học "bao gồm tất cả các loại hình nghiên cứu, giảng dạy hoặc đào tạo về nghiên cứu sau bậc trung học, được cung cấp bởi các trường đại học hoặc các cơ sở giáo dục khác được cơ quan nhà nước có thẩm quyền phê duyệt là tổ chức giáo dục đại học" (UNESCO, 1998).

Như vậy có thể hiểu quan hệ hợp tác Việt Nam - Hoa Kỳ trong lĩnh vực giáo dục đại học là hợp tác quốc tế diễn ra song phương giữa Việt Nam và Hoa Kỳ trong lĩnh vực giáo dục đại học bao gồm mọi hoạt động hợp tác về nghiên cứu, giảng dạy, đào tạo bậc đại học dưới sự phê duyệt của Chính phủ và các cơ quan có thẩm quyền của hai nước. 


\subsection{Một số vấn đề lý luận về quan hệ hợp tác Việt Nam - Hoa Kỳ trong lĩnh vực}

giáo dục đại học

\subsubsection{Vai trò của họp tác giáo dục đại học trong chính sách đối ngoại của Việt}

\section{Nam và Hoa Kỳ}

Trong cuốn "Sổ tay Thuật ngữ Quan hệ Quốc tế" do Đào Minh Hồng - Lê Hồng Hiệp đồng chủ biên, các tác giả đưa ra khái niệm về chính sách đối ngoại của một quốc gia là tập hợp các chiến lược mà quốc gia đó sử dụng trong quá trình tương tác với các quốc gia khác và các tổ chức quốc tế, trên cách lĩnh vực kinh tế, chính trị, quân sự, văn hóa - xã hội, nhằm đạt được những mục tiêu khác nhau phù hợp với lợi ích của quốc gia đó. Chính sách đối ngoại có mục đích nhất định và đóng vai trò ngày càng quan trọng đối với các vấn đề quốc gia, đặc biệt trong thời đại toàn cầu hóa ngày nay, khi không quốc gia nào có thể tồn tại biệt lập và sự giao lưu, hợp tác ngày càng được chú trọng (Dao \& Le, 2013).

Với các hoạt động hợp tác nghiên cứu, giảng dạy, đào tạo bậc đại học dưới sự phê duyệt của Chính phủ và các cơ quan có thẩm quyền của hai nước, hợp tác trong lĩnh vực giáo dục đại học là một trong những khía cạnh được triển khai từ chính sách đối ngoại của Việt Nam và Hoa Kỳ, là một trong những hoạt động hợp tác quốc tế song phương diễn ra giữa hai nước. Đặc biệt hợp tác trong lĩnh vực giáo dục đại học còn là một hình thức điển hình của công tác đối ngoại công chúng.

Tìm hiểu khái niệm của đối ngoại công chúng, thực chất hoạt động đối ngoại công chúng đã được tiến hành từ lâu đời trong lịch sử quan hệ quốc tế như "Hoàng đế La Mã từng nhận dạy dỗ con trai của các vị hoàng đế láng giềng thân thiện; người Hy Lạp cổ đại đã xây dựng thư viện khổng lồ Alexandria như một hình thức truyền bá tri thức; Hoàng đế La Mã Frederick II đã phân phát các bản tin sang các khu vực lân bang” (Vu, 2009), song, đến nay vẫn chưa có một định nghĩa chung thống nhất về đối ngoại công chúng.

Tại Hoa Kỳ, đối ngoại công chúng hay ngoại giao công chúng đều sử dụng bằng thuật ngữ "public diplomacy". Khái niệm về thuật ngữ này lần đầu tiên được nhà ngoại giao Edmund Gullion đưa ra vào năm 1965: Đối ngoại công chúng xử lý những vấn đề liên quan tới tác động của công chúng đối với quá trình hình thành và thực hiện chính sách đối ngoại. Đối ngoại công chúng đề cập đến những khía cạnh của quan hệ quốc tế, bên cạnh hình thức ngoại giao truyền thống; định hướng quan điểm dư luận của chính phủ ở các nước khác; mối quan hệ giữa các nhóm lợi ích của nước này với những nước kia; báo cáo về các vấn đề đối ngoại và tác động tới chính sách; thông tin, tiếp xúc giữa các nhà ngoại giao và giới truyền thông nước ngoài; các quá trình thông tin, giao lưu giữa các nền văn hóa. Trọng tâm của đối ngoại công chúng là luồng thông tin và ý tưởng xuyên quốc gia (Cull, 2008). 
Tuy nhiên ở thời điểm đó, đối ngoại công chúng được xem như bức bình phong của công tác tuyên truyền (propaganda), một cách tiêu cực dẫn dắt dư luận theo chiều hướng đem lại lợi ích cho một nhóm hoặc chính phủ nào đó. Cho đến những thập kỷ gần đây, đối ngoại công chúng được nhìn nhận rộng hơn, đó là phương tiện minh bạch mà một quốc gia có chủ quyền, giao tiếp với công chúng quốc gia khác nhằm mục đích thông tin cũng như tạo ảnh hưởng để thúc đẩy đạt được lợi ích và các mục tiêu chính sách đối ngoại của mình.

Tại Việt Nam, khái niệm “đối ngoại công chúng” còn khá mới mẻ. Trong các nghiên cứu về công tác đối ngoại, ngoại giao, hướng tiếp cận thường là chủ thể thực hiện (kênh đối ngoại) bao gồm đối ngoại Đảng, ngoại giao nhà nước, đối ngoại nhân dân; hay theo lĩnh vực hoạt động bao gồm ngoại giao chính trị, ngoại giao kinh tế, ngoại giao văn hóa. Trong khi đó, đối ngoại công chúng được tiếp cận theo hướng đối tượng tiếp nhận (Pham, 2016). Khái niệm “đối ngoại công chúng” thường được hiểu gần nhất với "ngoại giao công chúng”, tức là các hoạt động đối ngoại, ngoại giao không hướng đến đối tượng như ngoại giao truyền thống là các thành phần chính phủ, lãnh đạo và nhà ngoại giao, mà hướng đến đối tượng công chúng hay thành phần phi chính phủ của nước ngoài. Tuy nhiên, khái niệm đối ngoại công chúng rộng hơn khái niệm ngoại giao công chúng. Nếu ngoại giao công chúng được hiểu là "các hoạt động ngoại giao của chính phủ hướng tới công chúng nước ngoài làm cho họ hiểu tư tưởng và quan điểm, thể chế và văn hóa cũng như các mục tiêu quốc gia và các chính sách hiện hành của mình", thì đối ngoại công chúng không chỉ bao gồm chủ thể là các chính phủ mà còn bao gồm các thành phần phi chính phủ bao gồm cả các tổ chức, cá nhân tiến hành. Như vậy, khái niệm đối ngoại công chúng có thể hiểu "là việc quan hệ với công chúng (thành phần phi chính phủ) nước ngoài để thực hiện chính sách đối ngoại quốc gia”, bao gồm các hoạt động đối ngoại do cả chính phủ và công chúng tiến hành nhằm tạo ảnh hưởng đến công chúng của quốc gia khác và thông qua công chúng khiến chính phủ thực hiện những chính sách đối ngoại có lợi (Pham, 2016).

Hoạt động hợp tác giáo dục đại học có thể coi là một hình thức hoạt động hiệu quả của đối ngoại công chúng bởi đối tượng được hướng tới của công tác đối ngoại này là các sinh viên, giảng viên, học giả, tức là công chúng của một quốc gia. Trong sự phát triển mạnh mẽ ở thế kỷ XXI, chủ thể thực hiện công tác đối ngoại này không chỉ là Chính phủ, cơ quan Ngoại giao của quốc gia mà còn bao gồm các tổ chức phi chính phủ, các tổ chức giáo dục, các cơ sở giáo dục đại học, các tập đoàn, doanh nghiệp và thậm chí bản thân người học và giảng dạy cũng tham gia vào công tác đối ngoại công chúng của Việt Nam và Hoa Kỳ. Do vậy có thể thấy hợp tác giáo dục đại học là một lĩnh vực quan trọng để hai quốc gia thực hiện các hoạt động cụ thể triển khai từ chính sách đối ngoại công chúng của mình. 


\subsubsection{Chính sách hợp tác giáo dục ở bậc đại học của Hoa Kỳ với Việt Nam}

Hoa Kỳ đã sớm nhận thức được tầm quan trọng và tiến hành các hoạt động trao đổi giáo dục đối với quan hệ giữa Hoa Kỳ và các quốc gia khác thông qua các chính sách đối ngoại của mình. Năm 1919, Viện Giáo dục Quốc tế (IIE) là một tổ chức phi lợi nhuận có trụ sở chính tại New York, được thành lập nhằm mục đích thúc đẩy hòa bình và hiểu biết giữa Hoa Kỳ và các quốc gia khác thông qua hoạt động trao đổi giáo dục (Pham, 2016). Viện Giáo dục Quốc tế là tổ chức phi chính phủ tuy nhiên vẫn được Chính phủ Hoa Kỳ tài trợ, do đó có thể thấy Chính phủ Hoa Kỳ nắm bắt được tầm quan trọng và thể hiện sự quan tâm tới vấn đề hợp tác giáo dục.

Các hoạt động trao đổi giáo dục và văn hóa được Chính phủ Hoa Kỳ đặc biệt lưu tâm từ thời điểm sau thế chiến II, trong sự cạnh tranh với Liên Xô và tư tưởng cộng sản đang phát triển và được truyền bá mạnh mẽ. Trong hoạt động thúc đẩy các hoạt động trao đổi giáo dục trong thời gian này, sự ra đời của chương trình Fulbright được đánh giá là một trong những chương trình nổi bật nhất của Chính phủ Hoa Kỳ. Năm 1945, Thượng nghị sĩ J. William Fulbright đã đề xuất một dự luật tại Quốc hội Hoa Kỳ kêu gọi sử dụng tài sản dư thừa sau chiến tranh để tài trợ cho việc thúc đẩy thiện chí quốc tế thông qua trao đổi giáo dục, văn hóa và khoa học của sinh viên. Năm 1946, Tổng thống Truman ký quyết định thông qua dự luật, Quốc hội Hoa Kỳ thành lập chương trình Fulbright, tạo bước tiến quan trọng trong sự phát triển của các hoạt động trao đổi giáo dục sau đó.

Trên cơ sở Đạo luật Fulbright năm 1946, Quốc hội tiếp tục mở rộng các chương trình trao đổi giáo dục thông qua ban hành năm 1961. Theo đạo luật này, các chương trình trao đổi giáo dục được thực hiện như một hoạt động của đối ngoại công chúng. Bốn mục đích của Đạo luật Trao đổi Giáo dục và Văn hóa được nêu ra trong phần 101:

Tăng cường sụ hiểu biết giũa nhân dân Hoa Kỳ với nhân dân các nước khác bằng các phương tiện trao đổi giáo dục và văn hóa;

Tăng cuờng mối quan hệ đoàn kết của Hoa Kỳ với các quốc gia khác bằng cách chứng minh sụ quan tâm, phát triển và thành tựu về giáo dục và văn hóa của Hoa Kỳ và các quốc gia khác, và nhũng đóng góp nhằm tạo nên một cuộc sống hòa bình, tốt đẹp cho mọi ngườ dân trên toàn thế giới;

Thúc đẩy hợp tác quốc tế về giáo dục và văn hóa;

Hỗ trọ̣ thúc đẩy mối quan hệ thân thiện, giao cảm và hòa bình giữa Hoa Kỳ và các quốc gia khác trên thế giới.

Phần 102 chỉ rõ vai trò của Tổng thống là được ủy quyền hành động khi nhận thấy các bước hành động tạo ra sự thúc đẩy trong hợp tác quốc tế. 
Phần 103 cho phép Tổng thống Hoa Kỳ ký kết các thỏa thuận quốc tế với Chính phủ các nước và các tổ chức quốc tế nhằm thúc đẩy các mục đích của Đạo luật này, và cung cấp sự tham gia công bằng, hỗ trợ cho việc thực hiện các thỏa thuận này.

Phần 104 cho phép Tổng thống ủy quyền cho các viên chức khác của Chính phủ được cho là thích hợp. Bộ Ngoại giao và Cơ quan Phát triển Hoa Kỳ (USAID) chịu trách nhiệm phần lớn các hoạt động trao đổi Hoa Kỳ tài trợ. Tuy nhiên, một số cơ quan liên bang khác, ví dụ như Viện Y tế Quốc gia, cũng chịu trách nhiệm quản lý các chương trình trao đổi dưới sự ủy quyền của Tổng thống.

Đạo luật cũng đề cập đến việc thành lập Văn phòng Giáo dục và Văn hóa trong Bộ Ngoại giao, chịu trách nhiệm quản lý, điều phối và giám sát các chương trình và trao đổi khác nhau, bao gồm chương trình trao đổi J. William Fulbright, Hubert H. Humphrey Chương trình học bổng, Chương trình Khách tham quan quốc tế, Trung tâm văn hóa và thư viện Hoa Kỳ ở nước ngoài, và nhiều chương trình khác (United State Congress, 1961).

Những cơ sở trên thúc đẩy hoạt động trao đổi giáo dục diễn ra sôi nổi giữa Hoa Kỳ và nhiều quốc gia khác, giúp Hoa Kỳ thành công trong việc thực hiện chính sách đối ngoại với mục đích “cho thế giới biết về xã hội và nền chính trị của Hoa Kỳ, đặc biệt là những cam kết của Hoa Kỳ đối với việc đảm bảo sự đa dạng văn hóa và tự do cá nhân” trong suốt thời kỳ Chiến tranh lạnh. Tuy nhiên, đối với Việt Nam, cuộc chiến tranh Đông Dương tạo ra một sự căng thẳng lớn trong quan hệ hai nước Việt Nam và Hoa Kỳ. Năm 1975 chiến tranh kết thúc, Hoa Kỳ rút quân khỏi Việt Nam, quan hệ Việt Nam - Hoa Kỳ chính thức đóng băng khi Hoa Kỳ ra lệnh cấm vận, khấu trừ hỗ trợ kinh tế và tài chính cho Việt Nam. Bản thân Việt Nam cũng chưa nguôi ngoai nỗi đau mất mát sau chiến tranh, lại chưa nhận được viện trợ tái thiết sau chiến tranh thích đáng từ Hoa Kỳ, do đó không dễ dàng đồng ý thiết lập quan hệ ngoại giao với Hoa Kỳ, và hoạt động trao đổi trên lĩnh vực giáo dục giữa hai nước gần như không được thực hiện trong thời gian này. Cho đến năm 1986, với chính sách Đổi mới, Việt Nam thể hiện tinh thần cởi mở, mong muốn sự hợp tác về kinh tế, con người với các nước tư bản phương Tây có thể đem lại những lợi ích phát triển cho Việt Nam. Trước chính sách mở cửa này, Hoa Kỳ đã nhận thấy cơ hội lớn để có thể thực hiện tiến trình bình thường hóa với Việt Nam. Trong quá trình tiến đến bình thường hóa quan hệ, giáo dục là một trong những lĩnh vực đóng vai trò quan trọng, với mục đích của Hoa Kỳ lúc bấy giờ, các chương trình trao đổi giáo dục là một cách để duy trì liên lạc và cũng là một cơ chế để tìm hiểu cộng đồng giáo dục Việt Nam (Abuza, 1996). Năm 1992, chương trình Fulbright được bắt đầu tại Việt Nam với mục đích gia tăng sự hiểu biết lẫn nhau giữa hai quốc gia Hoa Kỳ và Việt Nam cũng như góp phần tiến đến bình thường hóa quan hệ ngoại giao giữa hai nước. 
Hoạt động trao đổi giáo dục tiếp tục đóng vai trò quan trọng trong quan hệ quốc tế của Hoa Kỳ nói chung và trong quan hệ với Việt Nam nói riêng kể từ khi chương trình Fulbright đầu tiên được thực hiện với Việt Nam, đặc biệt là vai trò góp phần tiến đến chính thức bình thường hóa quan hệ Việt Nam - Hoa Kỳ vào năm 1995. Tuy nhiên, thập kỷ 90 của thế kỷ XX với những biến động lớn bao gồm sự tan rã của Liên Xô, chứng minh được sức ảnh hưởng của Hoa Kỳ trong quan hệ quốc tế, sự suy yếu về kinh tế của Hoa Kỳ khiến nước này không chú trọng phát triển các chương trình trao đổi giáo dục cũng như hoạt động đối ngoại công chúng nói chung. Điều này phần nào đã gây ra hậu quả cho Hoa Kỳ khi chỉ tập trung vào các vấn đề đối nội và có phần yêu thích hơn các biện pháp sử dụng "sức mạnh cứng” phô trương sức mạnh, nặng nề nhất chính là vụ khủng bố 11 tháng 9 năm 2001. Sự kiện khủng bố chính là dịp để Hoa Kỳ nghiêm túc nhìn nhận lại vai trò của "sức mạnh mềm", trong đó có các hoạt động trao đổi giáo dục trong chính sách đối ngoại của mình. Khái niệm "sức mạnh mềm" được hiểu là khả năng đạt được những gì muốn thông qua sự hấp dẫn hơn là ép buộc hoặc thanh toán và sử dụng sự hấp dẫn của nền văn hóa, lý tưởng chính trị và các chính sách của một quốc gia để thu hút, tạo sức ảnh hưởng tới các quốc gia khác (Nye, 2005). Hợp tác quốc tế trên giáo dục là một lĩnh vực then chốt mà sức mạnh mềm được áp dụng và chứng minh là thành công. Hoa Kỳ và các trường đại học của Hoa Kỳ, với nhiều lượng kiến thức bổ ích, cho rằng có thể tạo ra lợi ích cho các quốc gia khác nếu họ có thể học và áp dụng các kiến thức cơ bản cho đất nước mình. Do đó, sinh viên được cho là những đối tượng quan trọng có thể truyền bá thông tin và sức ảnh hưởng ở nước ngoài, là những người đi học tại Hoa Kỳ, nhận bằng cấp tầm cỡ thế giới và trở về quê hương, không chỉ sử dụng những kiến thức được học vào việc thực hiện tạo ra lợi ích cho quốc gia mình, mà còn mang về đó những chia sẻ về văn hóa, trải nghiệm tại Hoa Kỳ (Robbins, 2013).

Như vậy có thể thấy hợp tác giáo dục luôn duy trì vị trí quan trọng trong chính sách đối ngoại của Hoa Kỳ, góp phần giúp Hoa Kỳ thực hiện mục tiêu truyền bá, lan tỏa những giá trị, văn hóa của mình, mở rộng sức ảnh hưởng không chỉ bằng "sức mạnh cứng” mà bằng “sức mạnh thông minh" tức là sự kết hợp cùng với "sức mạnh mềm”. Việt Nam cũng không nằm ngoại lệ với chính sách đối ngoại này của Hoa Kỳ. Hơn vậy, Việt Nam còn có những yếu tố riêng để Hoa Kỳ thúc đẩy quan hệ hợp tác giữa hai nước thông qua lĩnh vực giáo dục, bao gồm lịch sử cựu thù giữa hai nước, việc thiết lập lại quan hệ ngoại giao cũng là nền tảng cho các hoạt động hợp tác giữa hai nước trong đó có giáo dục, và vị trí địa chính trị quan trọng của Việt Nam trong khu vực Đông Nam Á cũng như Châu Á - Thái Bình Dương cho thấy tiềm năng của Việt Nam thu hút sự tăng cường hợp tác trongchính sách đối ngoại của 
Hoa Kỳ. Năm 2000, Quốc hội Hoa Kỳ thông qua Đạo luật Quỹ giáo dục Việt Nam với mục đích:

(1) Thiết lập một chương trình học bổng quốc tế theo đó:

(A) Công dân Việt Nam có thể thực hiện các nghiên cứu bậc đại học và sau đại học về khoa học (tự nhiên, vật lý và môi trường), toán học, y học và công nghệ (bao gồm cả công nghệ thông tin);

(B) Công dân Hoa Kỳ có thể giảng dạy trong các lĩnh vực được quy định tại điểm (A) trong các cơ quan thích hợp của Việt Nam.

(2) Tiếp tục quá trình hòa giải giữa Hoa Kỳ và Việt Nam và xây dựng mối quan hệ song phương phục vụ lợi ích của cả hai quốc gia. (United States Congress, 1961)

\subsubsection{Chính sách hợp tác giáo dục ở bậc đại học của Việt Nam với Hoa Kỳ}

Trong lịch sử Việt Nam, giáo dục phần lớn chịu tác động bởi các quốc gia bên ngoài do gắn liền với yếu tố chính trị. 1000 năm Trung Quốc đô hộ cùng chính sách đồng hóa, dù là một đất nước giàu văn hóa và tinh thần dân tộc cao, Việt Nam vẫn đã chịu những ảnh hưởng nhất định từ với nền văn hóa nặng tính Khổng giáo (Hoang \& Dung, 2009; Vuong et al., 2018), trong đó bao gồm cả lĩnh vực giáo dục. Năm 1076 đời vua Lý Nhân Tông, Quốc Tử Giám - trường đại học đầu tiên của Việt Nam được xây dựng, ban đầu có ý định chỉ dạy cho con cháu hoàng tộc, sau đó quyết định thu nhận đào tạo nhân tài từ khắp nơi trong cả nước để trở thành quan lại góp công trị nước. Với tư tưởng chính trị chủ đạo là Nho giáo, trường đại học dạy lịch sử, văn học và những tư tưởng Nho giáo, kiến thức mang tính thực hành không được đề cao trong giai đoạn này. Sự thay đổi về nội dung giáo dục diễn ra khi Việt Nam chịu ách cai trị của thực dân Pháp, năm 1906, trường Đại học Đông Dương là trường đại học đầu tiên ở Việt Nam được xây dựng theo mô hình của Pháp với các chuyên ngành khoa học cơ bản, khoa học kỹ thuật, khoa học xã hội - nhân văn, luật, y dược,... Sinh viên học tiếng Pháp, các chuyên ngành đào tạo nhưng chủ yếu là để phục vụ cho chính quyền hành chính hoặc thực dân Pháp. Đây cũng là khoảng thời gian những thanh niên Việt Nam ưu tú được chọn gửi ra nước ngoài học tập, tuy nhiên với mục đích chính trị là tìm ra con đường cứu nước khỏi ách thống trị. Sự ảnh hưởng của các quốc gia bên ngoài trên lĩnh vực giáo dục tiếp tục sau khi cuộc kháng chiến chống Pháp diễn ra, Việt Nam đòi quyền tự trị khỏi tay thực dân Pháp nhưng bị chia cách hai miền Nam - Bắc qua vĩ tuyến 17. Sau năm 1954, chính quyền ở miền Bắc xác định đi theo con đường chủ nghĩa xã hội, do đó hoạt động giáo dục đại học được tăng cường trao đổi với các quốc gia xã hội chủ nghĩa, nhiều sinh viên được gửi đi học ở các quốc gia Liên Xô và Đông Âu trong thời gian này. Trong khi đó tại miền Nam, chính quyền được trợ cấp bởi đế quốc Mỹ, mô hình xã hội và giáo dục cũng noi theo Mỹ. Một trong 
những chương trình hợp tác giáo dục tại đây do trường đại học Michigan liên hệ với chính quyền Ngô Đình Diệm, cung cấp những phương pháp sư phạm và thực hành với mục đích hỗ trợ phát triển kinh tế và phát triển nông nghiệp ở nông thôn miền Nam (University Archives \& Historical Collections of Michigan State University (n.d.)). Sau khi thống nhất đất nước năm 1975, hệ thống giáo dục Việt Nam được định hướng đào tạo với các mục tiêu có thể giúp đất nước tái kiến thiết sau chiến tranh, tuy nhiên các chương trình hầu hết chỉ dựa theo mô hình, sử dụng nguồn tài liệu, cơ sở vật chất và nhân lực do Liên Xô và các nước Đông Âu hỗ trợ. Thời gian này, sinh viên được gửi đi học các ngành nghề đào tạo tại các nước xã hội chủ nghĩa. Việc này tuy có vai trò hỗ trợ Việt Nam giúp khôi phục đất nước sau chiến tranh, nhưng sự hạn chế trong tự phát triển hệ thống giáo dục và giới hạn các quốc gia hợp tác khiến cho chất lượng giáo dục không có sự tiến bộ sau nhiều năm liền đồng thời cũng là một trong những lý do khiến cho nền kinh tế trở nên trì trệ, đất nước còn nhiều bất cập.

Trước yêu cầu phát triển kinh tế và xã hội, Việt Nam đã lập ra chương trình Đổi mới (1986), chủ trương mở cửa, dù chủ yếu tập trung vào lĩnh vực kinh tế với việc chuyển sang mô hình kinh tế thị trường song các lĩnh vực xã hội, trong đó có giáo dục cũng tạo ra sức ảnh hưởng lớn. Trước mong muốn phát triển về kinh tế, đặc biệt là nền kinh tế tri thức, Việt Nam cần có tiềm lực về những công nghệ mới, về đội ngũ nhân lực giàu kiến thức và kinh nghiệm. Tuy nhiên do hoàn cảnh đất nước trì trệ sau cuộc khôi phục kinh tế, cũng như nền tảng chưa đủ phát triển để đào tạo ra nguồn nhân lực tiếp nhận những công nghệ mới, do đó Việt Nam cần có sự trợ giúp từ những quốc gia phát triển, đã đi trước về ứng dụng thành tựu khoa học kỹ thuật hiện đại, thông qua con đường giáo dục đào tạo, đặc biệt là lớp thanh niên trẻ có khả năng tiếp thu kiến thức tiến bộ ở nước ngoài và quay về xây dựng đất nước. Dựa trên nhu cầu đó, cùng với chủ trương mở cửa, đổi mới tư duy giáo dục, Việt Nam đưa ra những thay đổi đối với giáo dục đại học và khuyến khích hoạt động hợp tác quốc tế trong giáo dục đại học, có xu hướng ngày càng phát triển mạnh mẽ nhất là khi bước sang thế kỷ XXI với nhiều cơ hội và thử thách. Trước sự bức thiết phải cải thiện chất lượng giáo dục đại học, Chiến lược phát triển giáo dục 2001-2010 và Đề án đổi mới giáo dục Việt Nam 2006-2020 đã đưa ra các mục tiêu phát triển giáo dục đại học thông qua hợp tác quốc tế:

Phát triển chiến lược hội nhập quốc tế cho hệ thống giáo dục đại học của đất nước trên cơ sở ký kết Hiệp định Thương mại Song phương Việt Mỹ (BTA), Khu vực mậu dịch tự do ASEAN (AFTA) và Hiệp định chung về Thương mại Dịch vụ (GATS);

Mở rộng hợp tác với các nước và các tổ chức nước ngoài để thành lập các trung tâm công nghệ cao trong các cơ sở giáo dục đại học và có khả năng cùng thực hiện các dự án nghiên cứu khoa học; 
Thực hiện đề án dạy và học bằng ngoại ngữ, đặc biệt là tiếng Anh. Lựa chọn và đưa vào sử dụng các chương trình đào tạo, giáo trình và tài liệu hiện đại đang được sử dụng ở các trường đại học nước ngoài và phù hợp với nhu cầu phát triển của Việt Nam trong các lĩnh vực khoa học tự nhiên, kỹ thuật, công nghệ và quản lý kinh tế;

Nâng cao chất lượng các chương trình nghiên cứu và đào tạo thể hiện đặc trưng cụ thể của quốc gia nhằm thu hút các nhà nghiên cứu và sinh viên nước ngoài, đồng thời duy trì bản sắc dân tộc và các giá trị truyền thống;

Tăng cường quan hệ quốc tế bằng cách trao đổi giảng viên và sinh viên, phối hợp với các trường đại học nước ngoài đào tạo và thực hiện các chương trình nghiên cứu; tiếp tục cử cán bộ giảng dạy và sinh viên đi du học ở các khu vực trọng điểm;

Xây dựng cơ chế, chính sách để tạo điều kiện và khuyến khích sinh viên du học tự túc về tài chính;

Phê chuẩn "Công ước công nhận văn bằng giáo dục đại học khu vực Châu Á - Thái Bình Dương", ký kết các hiệp định song phương và thành lập các tổ chức nhằm thúc đẩy các hoạt động liên quan;

Thiết lập các nguyên tắc, thủ tục rõ ràng và thuận lợi để khuyến khích các tổ chức giáo dục nước ngoài có kinh nghiệm, tiềm năng và trình độ cao thành lập các cơ sở giáo dục $100 \%$ vốn nước ngoài hoặc liên doanh với các đối tác Việt Nam trong giáo dục đại học, dạy nghề và giáo dục từ xa;

Thực hiện kiểm soát chất lượng trong các dịch vụ đào tạo (bao gồm các chương trình trực tuyến) do các cơ sở đào tạo nước ngoài cung cấp;

Tận dụng mọi cơ hội để thu hút các chuyên gia có trình độ cao từ nước ngoài đến hỗ trợ đào tạo và nghiên cứu, đồng thời xây dựng hệ thống chính sách thu hút người Việt Nam định cư ở nước ngoài và công dân Việt Nam được đào tạo ở nước ngoài trở lại và đóng góp xây dựng đất nước (Nguyen T. A., 2009).

Với những mục tiêu như vậy, năm 2000, Chính phủ Việt Nam ban hành Nghị định về hợp tác đầu tư với nước ngoài trong lĩnh vực giáo dục đào tạo trong đó Chương 3 , điều 10 đến 13 đưa ra các quy định về cơ sở giáo dục có vốn đầu tư nước ngoài, Chương 5 gồm điều 18 đến 23 khuyến khích và quy định những ưu đãi đầu tư đối với các nhà đầu tư nước ngoài tại Việt Nam.

Nghị định 18/2001 quy định về việc lập và hoạt động của các cơ sở văn hóa, giáo dục nước ngoài tại Việt Nam. Tuy nhiên cùng với sự phát triển của các chương trình liên kết của các cơ sở giáo dục Việt Nam và nước ngoài, năm 2012, Chính phủ Việt Nam ban hành Nghị định 73 quy định về hợp tác, đầu tư của nước ngoài trong lĩnh vực giáo dục, đưa ra những 
quy định, thủ tục cụ thể về các loại hình liên kết đào tạo giáo dục Việt Nam với các cơ sở giáo dục nước ngoài.

Đối với Hoa Kỳ - một quốc gia có mối quan hệ đặc biệt với Việt Nam, từ lịch sử là hai nước thù địch trong chiến tranh, cho đến khoảng thời gian đóng băng ngoại giao với lệnh cấm vận từ phía Hoa Kỳ và chính sách đóng cửa của Việt Nam tưởng chừng như hai nước không bao giờ có thể nối lại mối quan hệ. Cho đến khi Việt Nam quyết định thực hiện chính sách Đổi mới, chủ trương mở cửa hợp tác với tất cả các nước, bao gồm cả việc tái thiết lập quan hệ với các nước phương Tây, thì đây chính là cơ hội cho cả Việt Nam và Hoa Kỳ bắt đầu những bước bình thường hóa quan hệ. Trong Đại hội VI, nghị quyết 13 được thông qua, với chủ trương "thêm bạn, bớt thù" và "kiên quyết và chủ động chuyển cuộc đấu tranh từ tình trạng đối đầu hiện nay sang đấu tranh và hợp tác trong cùng tồn tại hoà bình”. Nghị quyết 13 cũng kiểm điểm và rút kinh nghiệm trong mối quan hệ với Hoa Kỳ, chỉ rõ chủ trương cần thúc đẩy từng bước quan hệ bình thường hóa Việt Nam - Hoa Kỳ cần có chính sách mới toàn diện đối với Mỹ nhằm tranh thủ dư luận nhân dân Mỹ và thế giới,... tạo điều kiện thuận lợi cho ta tập trung giữ vững hoà bình và phát triển kinh tế (Nguyen X. S., 2006). Về lĩnh vực giáo dục đại học, Hoa Kỳ là một trong những quốc gia đi đầu trên thế giới về giáo dục nói chung và giáo dục đại học nói riêng, minh chứng bởi việc Hoa Kỳ là quốc gia có nhiều trường đại học danh tiếng nhất thế giới. Việc mở rộng quan hệ với Hoa Kỳ, đặc biệt trên lĩnh vực giáo dục sẽ giúp Việt Nam học hỏi nhiều kinh nghiệm trong quá trình phát triển nền giáo dục đồng thời khai thác các nguồn tài trợ từ các dự án của chính phủ cũng như hợp tác song phương giữa các trường đại học Việt Nam và Hoa Kỳ. Hợp tác về giáo dục đại học là một trong những hình thức quan trọng trong việc góp phần bình thường hóa quan hệ hai nước cũng như làm sâu sắc mối quan hệ hợp tác giữa Việt Nam và Hoa Kỳ những năm sau bình thường hóa. Bên cạnh mục tiêu chính trị, hoạt động hợp tác giữa Việt Nam và Hoa Kỳ trên lĩnh vực giáo dục đại học còn giúp nhân dân hai nước tăng cường tình hữu nghị, hiểu biết lẫn nhau.

Dấu mốc quan trọng là năm 2013, Việt Nam và Hoa Kỳ thiết lập mối quan hệ đối tác toàn diện, xác định giáo dục đào tạo là một trong bốn ưu tiên hàng đầu. Quốc hội và Chính phủ hai nước đều dành ưu tiên cao cho hợp tác giáo dục, đặc biệt là giáo dục đại học, thông qua các chương trình cấp học bổng cho sinh viên và nghiên cứu sinh Việt Nam tại Hoa Kỳ, các chương trình trao đổi giảng viên và sinh viên, các chương trình đào tạo tiếng Anh cũng như các mô hình liên kết đào tạo giữa các trường cao đẳng và đại học của hai nước.

1.3. Một số vấn đề về thực tiễn quan hệ hợp tác Việt Nam - Hoa Kỳ trong lĩnh vục giáo dục đại học 
Mặc dù đã manh nha xuất hiện từ lâu trong lịch sử, song toàn cầu hóa được đánh giá có tốc độ phát triển mạnh mẽ chưa từng có vào những năm cuối thế kỷ $\mathrm{XX}$, gắn liền với sự phát triển của khoa học công nghệ, đặc biệt là trong lĩnh vực thông tin liên lạc, thể hiện tiêu biểu nhất qua vai trò của internet (Dao \& Le, 2013). Toàn cầu hóa giúp các quốc gia tích cực tham gia hội nhập vào hệ thống kinh tế toàn cầu thông qua các hiệp định thương mại tự do. Thời điểm đỉnh cao của sự nổi lên xu thế toàn cầu hóa là từ sau khi Chiến tranh Lạnh kết thúc khi mà thế giới có cơ hội kết nối với nhau nhiều hơn, đặc biệt về chính trị và kinh tế, vì vậy không thể phủ nhận rằng thực tế xu thế phát triển của toàn cầu hóa trong bối cảnh thế giới từ thập niên 90 của thế kỷ XX có những tác động nhất định đối với quan hệ hợp tác giữa các quốc gia, trong đó có quan hệ Việt Nam - Hoa Kỳ trong lĩnh vực giáo dục đại học được bắt đầu từ những năm đầu của thập kỷ 90 thế kỷ XX.

Thực tế đã cho thấy trong bối cảnh toàn cầu hóa, Hoa Kỳ là một quốc gia tích cực tham gia vào các tổ chức, diễn đàn kinh tế, thương mại khu vực và quốc tế, nhằm tăng cường vị thế của mình trên trường quốc tế cũng như tạo sức ảnh hưởng, thể hiện tinh thần thiện chí của mình với toàn cầu. Đối với Việt Nam, bắt đầu những năm tháng đổi mới còn nhiều bất cập nhất là nền kinh tế mà Việt Nam mong muốn có những cải cách vượt bậc, toàn cầu hóa là cơ hội để Việt Nam nắm bắt để tham gia những sân chơi lớn, đặc biệt trên các lĩnh vực kinh tế, thương mại. Do đó Việt Nam tích cực tham gia vào các tổ chức quốc tế và khu vực như trở thành thành viên của Hiệp hội các quốc gia Đông Nam Á ASEAN, tham gia Khu vực thương mại tự do ASEAN (AFTA), tham gia sáng lập Diễn đàn hợp tác Á - Âu (ASEM) và được kết nạp vào Diễn đàn hợp tác kinh tế Châu Á - Thái Bình Dương (APEC). Đặc biệt, Việt Nam đạt được một bước tiến quan trọng trong hội nhập kinh tế toàn cầu khi chính thức trở thành thành viên của Tổ chức Thương mại Thế giới (WTO) vào năm 2007.Việc tham gia vào các tổ chức quốc tế và khu vực vừa tạo cơ hội cho Việt Nam phát triển nền kinh tế, nhưng đồng thời cũng tạo ra cho Việt Nam những thách thức cần phải nỗ lực thúc đẩy nền kinh tế của bản thân cũng như của khu vực. Vì vậy để đáp ứng yêu cầu hội nhập và bắt kịp với xu thế phát triển mạnh mẽ của nhiều cường quốc, bên cạnh việc cải cách mô hình kinh tế một cách phù hợp, Việt Nam cần thúc đẩy tạo ra nguồn nhân lực chất lượng cao, mà phương pháp tối ưu chính là hợp tác trong lĩnh vực giáo dục đại học với các quốc gia phát triển.

Như vậy có thể thấy xu thế toàn cầu hóa và hội nhập kinh tế quốc tế và khu vực vừa tạo ra thách thức khiến Việt Nam phải tích cực chủ động hợp tác giáo dục, nhưng đồng thời cũng là cơ hội để việc hợp tác giáo dục với các quốc gia phát triển được dễ dàng, thuận lợi hơn bởi nền tảng là sự hợp tác chung lợi ích khi tham gia vào các tổ chức khu vực và quốc tế. Điển hình là việc Việt Nam thực hiện theo Hiệp định chung về Thương mại Dịch vụ (GATS) 
khi tham gia vào Tổ chức thương mại thế giới, theo đó Việt Nam thực hiện mở cửa với 11 ngành dịch vụ, trong đó có dịch vụ giáo dục, là cơ sở để Việt Nam thu hút nhiều hơn các nhà đầu tư giáo dục đến từ các nước phát triển trong đó có Hoa Kỳ và thúc đẩy hợp tác trên lĩnh vực giáo dục đại học.

Những năm đầu thế kỷ XXI phát triển nhanh chóng bởi tốc độ của khoa học, công nghệ thông tin, các nền kinh tế cũng vận động không ngừng. Trước thách thức phát triển nền kinh tế tri thức và nâng cao vị thế của bản thân trên trường quốc tế, Việt Nam càng có nhu cầu nâng cao chất lượng giáo dục đào tạo, nền tảng của mọi lĩnh vực chính trị, kinh tế, xã hội của đất nước. Việc gia tăng sự hợp tác kinh tế, thương mại với các quốc gia nước ngoài cũng như thu hút nhiều nhà đầu tư vào thị trường tại Việt Nam yêu cầu Việt Nam phát triển chất lượng giáo dục, bởi còn tồn tại một số hạn chế trong khả năng tự xây dựng cải cách hệ thống, nên nhu cầu hợp tác giáo dục với các quốc gia phát triển là điều tất yếu. 


\section{CHUOONG 2}

\section{THỰC TRẠNG QUAN HỆ HỢP TÁC VIẸT NAM - HOA KỲ TRONG LĨNH VỰC GIÁO DỤC ĐẠI HỌC TỪ NĂM 1992 ĐẾN NĂM 2015}

\subsection{Các nhân tố tác động đến quan hệ hợp tác Việt Nam - Hoa Kỳ trong lĩnh vụ̣c giáo dục đại học từ năm 1992 đến năm 2015}

\subsubsection{Nhân tố ngọ̣i sinh}

Từ sau khi Chiến tranh lạnh kết thúc năm 1992, thế giới và khu vực có những chuyển biến tích cực với xu thế toàn cầu hóa cũng như hội nhập quốc tế. Bối cảnh đó là cơ hội cho việc thực hiện các hoạt động hợp tác trên mọi lĩnh vực được dễ dàng, thuận lợi hơn ví dụ như kinh tế, thương mại, văn hóa, giáo dục. Xu thế đó cũng tạo ra thách thức, yêu cầu các nước hợp tác lẫn nhau để cùng phát triển, đáp ứng được nhu cầu phát triển kinh tế, chất lượng xã hội của bản thân quốc gia và các quốc gia cùng hợp tác. Không nằm ngoài xu thế này, Hoa Kỳ tích cực gia tăng vai trò của mình trong các tổ chức đa phương và thiết lập quan hệ song phương với các quốc gia, trong đó thực hiện bình thường hóa quan hệ ngoại giao với Việt Nam. Trong bối cảnh toàn cầu hóa và sự tích cực chủ động của nhiều cường quốc trong thúc đẩy quan hệ hợp tác với Việt Nam, Hoa Kỳ cũng cần trở nên tích cực, không để đánh mất vai trò hợp tác của mình với một đất nước mới nổi tiềm năng như Việt Nam. Đối với Việt Nam, những cơ hội và thách thức mà bối cảnh thế giới và khu vực đem lại thông qua xu thế toàn cầu hóa như việc tham gia vào các tổ chức khu vực và thế giới cũng như thiết lập quan hệ ngoại giao với hầu hết các quốc gia trên thế giới tạo cho Việt Nam xu hướng mới trong đường lối đối ngoại, trong Đại hội VII của Đảng (1991), Việt Nam nhấn mạnh và khẳng định chủ trương thực hiện đường lối đối ngoại “độc lập tự chủ, đa phương hóa, đa dạng hóa”.Quan hệ Việt Nam - Hoa Kỳ trong xu thế hội nhập và toàn cầu hóa được thúc đẩy hợp tác mạnh mẽ, đa dạng trên nhiều lĩnh vực, trong đó giáo dục là một lĩnh vực quan trọng.

\subsubsection{Nhân tố nội $\sinh$}

Việt Nam - Hoa Kỳ từng là cựu thù chiến tranh, sau đó đến thời kỳ đóng băng không hề có hoạt động ngoại giao nào diễn ra giữa hai nước. Chỉ đến khi Việt Nam thực hiện Đổi mới với những chính sách cởi mở hơn, hai nước mới có cơ hội dần nối lại quan hệ song phương. Với chính sách mở cửa của Việt Nam, Hoa Kỳ bắt đầu tiến hành hợp tác trên lĩnh vực giáo dục thông qua Chương trình Fulbright vào năm 1992, là một trong những lĩnh vực hợp tác đầu tiên trong quan hệ của hai nước và thúc đẩy quá trình bình thường hóa. Nhưng tiếp đó, chính quan hệ bình thường hóa được thiết lập lại là cơ sở để hoạt động hợp tác trên lĩnh vực giáo dục được tăng cường, hoạt động một cách sôi nổi. Có thể thấy quan hệ chính trị 
ngoại giao được hình thành tốt đẹp là cơ sở cho sự hợp tác song phương trên các lĩnh vực, trong đó có giáo dục đại học.

Bên cạnh nhân tố tác động là sự tái thiết lập quan hệ ngoại giao, hợp tác giáo dục đại học giữa Việt Nam và Hoa Kỳ từ năm 1992 đến năm 2015 còn được tác động bởi nhu cầu của bản thân hai quốc gia. Hoa Kỳ thông qua Đạo luật Trao đổi Giáo dục và Văn hóa năm 1961 thể hiện mong muốn "tăng cường sự hiểu biết giữa nhân dân Hoa Kỳ với nhân dân các nước khác bằng các phương tiện trao đổi giáo dục và văn hóa” cũng như "Thúc đẩy hợp tác quốc tế về giáo dục và văn hóa; Hỗ trợ thúc đẩy mối quan hệ thân thiện, giao cảm và hòa bình giữa Hoa Kỳ và các quốc gia khác trên thế giới” (United States Congress, 1961). Đồng thời Hoa Kỳ mong muốn tiếp tục đầu tư vào các quốc gia tiềm năng như Việt Nam - là một quốc gia lý tưởng để Hoa Kỳ thúc đẩy nâng cao chất lượng giáo dục, từ đó tạo ra một thị trường phát triển cho các hoạt động kinh tế cũng như kỹ thuật, công nghiệp của Hoa Kỳ. Trong khi đó Việt Nam là một quốc gia vực dậy sau sự trì trệ của nền kinh tế, chưa đủ năng lực để tự phát triển hệ thống giáo dục, và có nhu cầu cao về nguồn nhân lực chất lượng để phục vụ nền kinh tế tri thức cũng như thu hút đầu tư từ bên ngoài, do đó những mong muốn cải cách chất lượng giáo dục, cải thiện đầu tư giáo dục, khoa học công nghệ (Vuong, 2018) để tiến gần hơn tới đẳng cấp quốc tế đã thúc đẩy Việt Nam tích cực hợp tác với các quốc gia phát triển về giáo dục, đặc biệt là giáo dục bậc đại học như Hoa Kỳ.

Như vậy cả nhân tố ngoại sinh và nhân tố nội sinh đều tạo cơ hội cho sự phát triển sâu rộng quan hệ hợp tác trong lĩnh vực giáo dục đại học giữa Việt Nam và Hoa Kỳ.

\subsection{Các hình thức họ̣p tác trong lĩnh vực giáo dục đại học giữa Việt Nam và Hoa} Kỳ từ năm 1992 đến năm 2015

\subsubsection{Thông qua các chuơng trình trao đổi giáo dục đại học}

Trên cơ sở các Đạo luật về trao đổi giáo dục do Quốc hội Hoa Kỳ ban hành và các chính sách thúc đẩy hợp tác quốc tế trong giáo dục đại học của Đảng và nhà nước Việt Nam, giữa hai nước đã diễn ra nhiều chương trình trao đổi giáo dục dành cho sinh viên, giảng viên đại học, các chuyên gia, phần lớn được hỗ trợ học bổng bởi Chính phủ Hoa Kỳ. Trong hơn 20 chương trình học bổng được thực hiện từ những năm đầu thập niên 90 của thế kỷ XX, có một số chương trình thực sự nổi bật, mang lại hiệu quả cao cho quan hệ hợp tác giáo dục đại học giữa Việt Nam và Hoa Kỳ.

\subsubsection{Chuong trinh Fulbright}

Chương trình Fulbright là một trong những chương trình trao đổi giáo dục cung cấp học bổng quốc tế lớn nhất của Chính phủ Hoa Kỳ, được thành lập năm 1946 với mục đích “tăng cường sự hiểu biết lẫn nhau và mối quan hệ thân thiện, hòa bình giữa nhân dân Hoa Kỳ 
và nhân dân các quốc gia khác”. Chương trình nhận được tài trợ chính từ Quốc hội và Bộ Ngoại giao Hoa Kỳ. Bộ Ngoại giao Hoa Kỳ chịu trách nhiệm quản lý tổng thể chương trình Fulbright với các nhiệm vụ đặt mức độ ưu tiên, phân bổ nguồn và tài trợ, và trao quyền quản lý cho các tổ chức phi lợi nhuận ví dụ như Viện Giáo dục Quốc tế (IIE) thực hiện điều phối, sắp xếp các ứng cử viên của chương trình Fulbright tham gia vào các viện, trường đại học tại Hoa Kỳ. Tại hơn 155 quốc gia được Chính phủ Hoa Kỳ tài trợ chương trình học bổng Fulbright, Đại sứ quán thuộc Bộ Ngoại giao Hoa Kỳ được đặt tại mỗi nước có nhiệm vụ làm việc với đối tác thuộc Chính phủ nước đó, cung cấp các chính sách, thủ tục và tuyển chọn ứng cử viên tham gia vào chương trình Fulbright, thực hiện trao đổi giáo dục giữa hai nước.

Được bắt đầu thực hiện tại Việt Nam từ năm 1992, chương trình Fulbright là chương trình trao đổi giáo dục sớm nhất và lớn nhất giữa Việt Nam và Hoa Kỳ. Chương trình do Phòng Thông tin - Văn hóa (PAS) Đại sứ quán Hoa Kỳ tại Hà Nội đảm trách, làm việc với các tổ chức giáo dục và chính phủ của Việt Nam và Hoa Kỳ để cung cấp cơ hội học tập và nghiên cứu khoa học xã hội và nhân văn cho tất cả các ứng viên đủ điều kiện thông qua cuộc thi mở, dựa trên cơ sở thành tích học tập và làm việc chuyên ngành, không phân biệt chủng tộc, tôn giáo, giới tính hoặc liên kết. Chương trình Fulbright tại Việt Nam sau hơn 20 năm chính thức thực hiện 5 thành phần chính: Chương trình trao đổi học giả Hoa Kỳ, Chương trình trao đổi học giả Việt Nam, Chương trình trao đổi sinh viên Hoa Kỳ, Chương trình trao đổi sinh viên Việt Nam và Chương trình Giảng dạy Kinh tế tại Thành phố Hồ Chí Minh.

Chương trình trao đổi sinh viên Việt Nam được thực hiện sớm nhất tại Việt Nam từ năm 1992, trước khi Việt Nam và Hoa Kỳ bình thường hóa quan hệ vào năm 1995. Đến năm 1996, số sinh viên Việt Nam đã tham gia trao đổi lên đến 117, khiến cho chương trình Fulbright tại Việt Nam lớn nhất Châu Á lúc bấy giờ. Điều này cho thấy quá trình bình thường hóa thúc đẩy sự tin tưởng, hợp tác trên lĩnh vực giáo dục giữa hai quốc gia. Mục đích của chương trình trao đổi nhằm thúc đẩy sự hiểu biết, mối quan hệ giữa Hoa Kỳ và Việt Nam, cụ thể hơn là cung cấp tối đa cơ hội giáo dục ở nước ngoài cho các cá nhân chưa có cơ hội trước đây; trải nghiệm phải mang lại giá trị cho bản thân ứng cử viên tham gia, mang lại giá trị cho Việt Nam, đồng thời mang giá trị cho chính các tổ chức cung cấp giáo dục tại Hoa Kỳ; và sinh viên tham gia chương trình Fulbright cũng chính là các đại sứ văn hóa của cả Việt Nam và Hoa Kỳ. Khoảng thời gian đầu của chương trình trao đổi sinh viên Việt Nam, với mục đích chính mong muốn các ứng cử viên sau quá trình trao đổi học tập tại Hoa Kỳ sẽ quay lại đóng góp công sức cho công cuộc xây dựng đất nước, chương trình quy định một số chuyên ngành nhất định cho sinh viên Việt Nam: kinh tế, quan hệ quốc tế và các vấn đề nhân quyền trong đó bao gồm quản trị kinh doanh và chính sách công. Các sinh viên trở về nước trong 
thời gian này đã đóng góp cho đất nước trong việc phát triển các ngành công nghiệp tư nhân cũng như quan hệ ngoại giao, quản lý công và phát triển nông nghiệp, tác động đến các chính sách và sự phát triển trong nước. Đồng thời đó là những đại sứ tiềm năng, có vai trò điều phối trong mối quan hệ song phương Việt Nam - Hoa Kỳ. Chương trình trao đổi sinh viên Việt Nam ngày càng được mở rộng, cả về đối tượng và lĩnh vực học tập. Chương trình cho phép đối tượng tham gia đến từ mọi nơi trên lãnh thổ Việt Nam, đang học tập, làm việc tại các cơ sở thuộc chính phủ, phi chính phủ, tư nhân, trường học,... Lĩnh vực học tập được mở rộng trên tất cả các mảng về khoa học xã hội, nhân quyền, kinh tế. Dưới hai nhiệm kỳ của tổng thống Hoa Kỳ George W. Bush, chương trình trao đổi sinh viên Việt Nam của Fulbright mở rộng cơ hội cho sinh viên học tập ở các lĩnh vực báo chí, y tế, công tác xã hội, khoa học máy tính, quản lý giáo dục và TESOL (chứng chỉ quốc tế về phương pháp dạy tiếng Anh cho giáo viên tại các quốc gia coi tiếng Anh là ngoại ngữ). Chương trình Fulbright trao đổi sinh viên Việt Nam duy trì trao học bổng cho 20-25 ứng cử viên mỗi năm.

Chương trình Fulbright thúc đẩy nhiều hơn các hoạt động trao đổi giáo dục giữa Việt Nam và Hoa Kỳ. Năm 1997, Chương trình trao đổi sinh viên Hoa Kỳ lần đầu được thực hiện tại Việt Nam, với 5 sinh viên Hoa Kỳ được gửi tới Việt Nam để học tập các ngành như phát triển kinh tế và thương mại, cải cách giáo dục và chính sách. Đến năm 1998, 11 sinh viên tham gia chương trình trao đổi sinh viên Hoa Kỳ tại Việt Nam, tiếp tục học về kinh tế và giáo dục, nhưng các môn học đã được mở rộng thêm như văn học, lịch sử Đông Nam Á, môi trường, quy hoạch và phát triển đô thị. Có thể thấy bình thường hóa quan hệ đã tạo cơ hội cho các hoạt động trao đổi giáo dục phát triển, đối với Hoa Kỳ đây là cơ hội để sinh viên Hoa Kỳ được đến Việt Nam, không chỉ học tập và nghiên cứu để hiểu hơn về Việt Nam mà còn tạo ra những tác động tích cực, góp phần tăng cường quan hệ hữu nghị giữa hai nước. Từ năm 2001, số sinh viên Hoa Kỳ tham gia trao đổi tại Việt Nam duy trì từ 7 đến 10 sinh viên mỗi năm, các lĩnh vực trong chương trình trao đổi được mở rộng như y tế cộng đồng, nghiên cứu phụ nữ, các môn nghệ thuật như viết, nhiếp ảnh, quay phim.

Từ năm 1998, chương trình Fulbright đồng thời thực hiện tại Việt Nam Chương trình trao đổi học giả Việt Nam và Chương trình trao đổi học giả Hoa Kỳ, hai chương trình cho phép các giảng viên sang nước đối tác trong thời gian ngắn hạn để giảng dạy, nghiên cứu. Năm hoạt động đầu tiên 1998-1999, 3 giảng viên của Việt Nam tham gia vào chương trình trao đổi học giả Việt Nam, thực hiện nghiên cứu trên các lĩnh vực kinh tế, quản lý giáo dục và địa lý. Số lượng ứng cử viên tham gia tăng và duy trì qua từng năm, hoạt động giảng dạy và nghiên cứu được mở rộng thêm trên nhiều lĩnh vực như chính sách môi trường, quan trị nhân sự, phát triển chính sách công, ngôn ngữ,...Chương trình trao đổi học giả Hoa Kỳ cho 
phép các giảng viên, nhà nghiên cứu Hoa Kỳ giảng dạy và nghiên cứu từ 3 đến 10 tháng tại Việt Nam. Được phụ trách bởi Đại sứ quán Hoa Kỳ tại Việt Nam, các ứng cử viên Hoa Kỳ thực hiện giảng dạy, nghiên cứu tại các trường đại học, cao đẳng, các cơ quan chính phủ trên khắp Việt Nam. Năm 1998, chỉ có 1 giảng viên Hoa Kỳ tham gia chương trình trao đổi này trên lĩnh vực nghiên cứu luật, nhưng đến năm 1999 số lượng người tham gia đã lên 7 người, các lĩnh vực giảng dạy và nghiên cứu tại Việt Nam được mở rộng như quản trị kinh doanh, kinh tế, khoa học môi trường, quản trị công, cũng như giáo dục và văn học Hoa Kỳ. Hằng năm, chương trình Fulbright cấp 6 đến 8 học bổng cho các học giả Hoa Kỳ trao đổi tại Việt Nam. Hoạt động trao đổi học giả này cho phép hai quốc gia trao đổi, nghiên cứu để hiểu biết lẫn nhau sâu sắc hơn, đồng thời tạo cơ hội cho Việt Nam học hỏi trên những lĩnh vực Hoa Kỳ đã phát triển hơn.

Cũng nằm trong khuôn khổ hoạt động của chương trình Fulbright tại Việt Nam, Chương trình giảng dạy kinh tế Fulbright được thành lập năm 1994, từ sự phối hợp giữa Hội đồng các Tổ chức Học thuật Hoa Kỳ (ACLS), Chương trình Việt Nam thuộc Viện Phát triển Quốc tế Harvard (HIID) và Đại học Kinh tế Thành phố Hồ Chí Minh như là một công trình tiên phong về hợp tác giáo dục ở Việt Nam. Vào tháng 7 năm 2000, sau khi Viện Phát triển Quốc tế Harvard giải thể, Chương trình Việt Nam chuyển sang Trung tâm Doanh nghiệp và Chính phủ $(\mathrm{CBG})$ thuộc Trường Chính phủ John F. Kennedy. Chương trình nhận được sự tài trợ chính từ Vụ Văn hóa và Giáo dục, Bộ Ngoại giao Hoa Kỳ với mục đích nghiên cứu nhằm phát triển, đổi mới chính sách kinh tế và nền kinh tế của Việt Nam, thông qua nâng cao chất lượng hiểu biết và phân tích chính sách công. Từ ngày thành lập đến nay, chương trình tập trung hỗ trợ và thực hiện 3 sáng kiến trọng tâm: Giảng dạy, gồm chương trình Thạc sĩ Chính sách công và đào tạo ngắn hạn cao cấp; nghiên cứu, nhắm đến những vấn đề chính sách phức tạp mà Việt Nam đang đối mặt; và đối thoại chính sách, thông qua thảo luận với các nhà hoạch định chính sách Việt Nam và tham gia trao đổi về chính sách công ở Việt Nam. Chương trình đã thu hút hơn 1000 học viên đến từ 60 trên 63 tỉnh thành của Việt Nam, sau quá trình học tập đã công tác trong các cơ quan quản lý nhà nước, các trường đại học, khu vực tài chính ngân hàng, doanh nghiệp tư nhân, các công ty đa quốc gia và tổ chức phi lợi nhuận.

\subsubsection{Quỹ giáo dục Việt Nam (Vietnam Education Foundation - VEF)}

Bình thường hóa quan hệ Việt Nam - Hoa Kỳ mở ra cho hai nước cơ hội hợp tác trên nhiều lĩnh vực. Bên cạnh kinh tế thương mại và công nghệ kỹ thuật, cả hai đều xác định giáo dục là lĩnh vực ưu tiên, được quan tâm hàng đầu trong quan hệ song phương Việt Nam - Hoa Kỳ. Thông qua Đạo luật Quỹ giáo dục Việt Nam năm 2000, Quốc hội Hoa Kỳ thành lập Quỹ 
giáo dục Việt Nam nhằm tăng cường mối quan hệ song phương giữa Việt Nam và Hoa Kỳ thông qua các hoạt động trao đổi giáo dục. Quỹ giáo dục Việt Nam chính thức đi vào hoạt động từ năm 2003, với sứ mệnh giúp Việt Nam xây dựng và đạt sự xuất sắc trong lĩnh vực khoa học và công nghệ, bằng cách đó sẽ đưa Hoa Kỳ và Việt Nam đến gần nhau hơn. Cụ thể, Quỹ giáo dục Việt Nam hướng tới giúp Việt Nam thiết lập một cộng đồng khoa học, kỹ thuật, $\mathrm{y}$ tế và kỹ thuật có thể thực hiện chương trình giảng dạy và nghiên cứu phát triển, tạo ra tăng trưởng kinh tế, duy trì hợp tác khoa học với Hoa Kỳ. Đồng thời giúp Việt Nam học hỏi cũng như có khả năng đóng góp cho sự tiến bộ khoa học và công nghệ trên toàn cầu. Nhằm thực hiện sứ mệnh, chương trình tạo cơ hội cho những công dân Việt Nam có khả năng nhất đến các trường đại học hàng đầu của Hoa Kỳ để theo học các chương trình đào tạo sau đại học và sau đại học về khoa học và công nghệ, giúp Việt Nam tăng cường năng lực và xây dựng thể chế khoa học và công nghệ trong nước, những lĩnh vực thiết yếu cần được nâng cao trong công cuộc xây dựng nền kinh tế tri thức của Việt Nam những năm đầu thế kỷ XXI. Đồng thời Quỹ giáo dục Việt Nam kêu gọi tận dụng nguồn lực và huy động cộng đồng khoa học và giáo dục Hoa Kỳ để giúp Việt Nam tập trung vào các hoạt động chất lượng cao và mở rộng trên thế mạnh khoa học và công nghệ của Việt Nam, tạo điều kiện cho các giáo sư Hoa Kỳ tham gia giảng dạy tại các trường đại học ở Việt Nam.

Hàng năm Quốc hội Hoa Kỳ dành ngân sách 5 triệu đô-la cho các hoạt động trao đổi giáo dục của Quỹ giáo dục Việt Nam. Tập trung vào các ngành khoa học tự nhiên, vật chất, môi trường và các ngành kỹ thuật, toán học, khoa học sức khỏe, công nghệ thông tin, các hoạt động của Quỹ giáo dục Việt Nam được thực hiện thông qua 3 chương trình: Chương trình Học bổng, Chương trình Học giả và Chương trình Giáo sư Hoa Kỳ giảng dạy tại Việt Nam.

Chương trình Học bổng là chương trình trọng tâm của Quỹ giáo dục Việt Nam, đưa công dân Việt Nam sang Hoa Kỳ tham gia các chương trình học sau đại học, chương trình hợp tác với các trường đại học tại Hoa Kỳ hỗ trợ tài chính cho các học viên theo học tại Hoa Kỳ. Năm 2003, 19 công dân Việt Nam nhận học bổng của Quỹ giáo dục Việt Nam sang Hoa Kỳ học tập, chỉ một năm sau con số này đã tăng lên 82 người. Tính đến năm 2015 , chương trình đã hỗ trợ 547 nghiên cứu sinh Việt Nam theo học các chương trình sau đại học tại 99 trường đại học uy tín của Hoa Kỳ. Trong số đó, 290 nghiên cứu sinh đã hoàn thành chương trình dưới sự hỗ trợ của Quỹ giáo dục Việt Nam, hiện đang làm việc tại các ngành nghề khác nhau, đang tìm kiếm cơ hội việc làm trong nước hoặc một số học tiếp chương trình tiến sĩ và số ít ở lại Hoa Kỳ theo các dạng thị thực khác nhau.

Chương trình Học giả được bắt đầu từ năm 2007, hỗ trợ các tiến sĩ Việt Nam theo học các chương trình sau tiến sĩ, kéo dài từ 5-12 tháng tại các trường đại học danh tiếng của Hoa 
Kỳ, nhằm thúc đẩy khả năng nghiên cứu và lãnh đạo của họ trong lĩnh vực khoa học và công nghệ.

Năm 2008, Chương trình Giáo sư Hoa Kỳ giảng dạy tại Việt Nam được bắt đầu, tính đến năm 2015, 34 giáo sư Hoa Kỳ đã được tuyển chọn để giảng dạy bằng tiếng Anh tại 26 trường đại học Việt Nam qua hình thức giảng dạy trực tiếp tại Việt Nam hoặc qua tương tác trực tuyến. Cả hai chương trình trao đổi học giả này đã thúc đẩy sự hợp tác giữa các nhà nghiên cứu và các nhà nghiên cứu chuyên nghiệp, cho phép cả học giả Việt Nam và Hoa Kỳ tìm hiểu về hệ thống giáo dục đại học lẫn nhau ở hai quốc gia.

Bên cạnh ba chương trình chính, Quỹ giáo dục Việt Nam thiết lập chương trình Tăng cường năng lực cho Việt Nam với mục đích thúc đẩy giao lưu hợp tác giữa chính phủ cũng như các cơ sở giáo dục đại học của Hoa Kỳ và Việt Nam, đồng thời tăng cường phát triển khoa học và công nghệ tại Việt Nam, tạo cơ hội cho những người đã học tại Hoa Kỳ theo chương trình học bổng có thể quay về Việt Nam đóng góp công sức hiệu quả cho sự phát triển của đất nước. Theo báo cáo tổng quát của Quỹ giáo dục Việt Nam năm 2015, chương trình Tăng cường năng lực cho Việt Nam đã thực hiện hiệu quả các hoạt động:

80 nhà khoa học từ 58 cơ quan nghiên cứu của Hoa Kỳ được tài trợ để thực hiện 197 bài giảng/thuyết trình tại 66 trường đại học và viện nghiên cứu của Việt Nam.

11 hội thảo/hội nghị khoa học được tổ chức, tài trợ 29 chuyên gia, đại diện cho 16 tổ chức giáo dục của Hoa Kỳ đến thuyết trình trong các sự kiện khoa học này tại Việt Nam.

3 báo cáo nghiên cứu về giáo dục đại học Việt Nam đã được hoàn thành:

(1) Những quan sát về giáo dục đại học trong các ngành khoa học máy tính, kỹ thuật điện-điện tử-viễn thông, và vật lý tại một số trường đại học Việt Nam (tháng 8 năm 2006);

(2) Những quan sát về hiện trạng giáo dục trong các ngành khoa học nông nghiệp tại Việt Nam (tháng 1 năm 2007);

(3) Những quan sát về hiện trạng giáo dục trong các ngành khoa học nông nghiệp, xây dựng, công nghệ thông tin, kỹ thuật điện - điện tử - viễn thông, khoa học môi trường, vật lý và giao thông vận tải tại một số trường đại học Việt Nam (tháng 7 năm 2014).

Xây dựng, phát triển các chương trình, dự án đặc biệt ví dụ như phối hợp cùng Viện nghiên cứu cao cấp (Princeton, NJ) và Nhóm Sáng kiến Khoa học (2004-2006) tạo ra Sáng kiến Khoa học Thiên niên kỷ (MSI), nhằm thành lập các Trung tâm Xuất sắc tại Việt Nam về khoa học và công nghệ, sáng kiến được triển khai theo yêu cầu của Bộ Khoa học và Công nghệ hay tổ chức các hội thảo tại Việt Nam: Gặp mặt các Nhà Khoa học trẻ Việt Nam (tháng 6 năm 2005, tháng 7 năm 2007); Hội thảo Kỹ thuật Y sinh Quốc tế (tháng 7 năm 2007); và Hội nghị Học liệu Mở Quốc tế (OCWC) (tháng 5 năm 2010). 
Hỗ trợ Cục Đào tạo với Nước ngoài (VIED) của Bộ Giáo dục và Đào tạo xây dựng chương trình học bổng theo mô hình của Quỹ giáo dục Việt Nam

Hỗ trợ Quỹ Phát triển Khoa học và Công nghệ Quốc gia (NAFOSTED) của Bộ Khoa học Công nghệ xây dựng Hệ thống Quản lý Trực tuyến

Cùng với Đại sứ quán Hoa Kỳ tại Việt Nam và Bộ Giáo dục và Đào tạo đồng tổ chức và tài trợ Hội nghị Giáo dục Thường niên lần thứ 4 tại Việt Nam vào tháng 4 năm 2011 nhằm tăng cường giao lưu giáo dục đại học giữa Hoa Kỳ và Việt Nam.

\subsubsection{Một số chương trình học bổng khác}

Ngoài hai chương trình học bổng nổi bật như Fulbright và Quỹ giáo dục Việt Nam, có hàng loạt các chương trình học bổng trao đổi giáo dục đại học nổi bật khác nằm trong quan hệ hợp tác giáo dục đại học Việt Nam - Hoa Kỳ do Chính phủ trực tiếp tài trợ hoặc tạo điều kiện, khuyến khích các tổ chức phi chính phủ và tổ chức về giáo dục tiến hành.

Có thể kể đến chương trình Hubert H. Humphrey chủ yếu do Quốc hội Hoa Kỳ tài trợ thông qua Vụ Văn hóa và Giáo dục của Bộ Ngoại giao Hoa Kỳ, ngoài ra được tài trợ bởi các cơ quan chính phủ, các tổ chức đa quốc gia và các doanh nghiệp tư nhân (The Hubert $\mathrm{H}$. Humphrey Fellowship Program). Đây là một chương trình học bổng nghiên cứu học tập kéo dài một năm dành cho những người có chuyên môn, kinh nghiệm trên các lĩnh vực công. Chương trình bao gồm thời gian học tập nghiên cứu trong các trường đại học và có thể có một kì thực tập chuyên môn ngoài trường đại học. Những lĩnh vực được khuyến khích tham gia bao gồm các lĩnh vực công: y tế công cộng, môi trường, giáo dục, luật, nhân quyền, chính sách công, chính sách và quản lý công nghệ, quy hoạch đô thị, báo chí, an ninh quốc gia, phòng chống, chữa trị và giáo dục về ma túy. Để được xem xét cấp học bổng, ứng cử viên tham gia chương trình được yêu cầu phải có bằng đại học, tối thiểu năm năm kinh nghiệm chuyên môn, hạn chế hoặc không có kinh nghiệm trước đó tại Hoa Kỳ, chứng minh phẩm chất lãnh đạo, thành tích phục vụ cho cộng đồng và kỹ năng tiếng Anh tốt (tối thiểu 525 điểm TOEFL). Hàng năm, tối đa bảy cán bộ cấp trung của Việt Nam có thể được đề cử tham gia chương trình này (U.S. Embassy \& Consulate in Vietnam).

Một chương trình trao đổi giáo dục nổi bật dành cho sinh viên đại học được tài trợ bởi Vụ Giáo dục và Văn hoá thuộc Bộ Ngoại giao Hoa Kỳ là UGRAD. Học bổng UGRAD dành cho sinh viên đại học xuất sắc cơ hội nghiên cứu toàn thời gian trong vòng một học kỳ tài trường đại học diện bốn năm tại Hoa Kỳ, ngoài ra sinh viên được tham gia vào các hoạt động cộng đồng, các hội thảo phát triển nghề nghiệp và giao lưu văn hóa. Sinh viên sẽ phải tham gia tối thiểu 20 giờ hoạt động cộng đồng trong chương trình. Sinh viên cũng phải đăng ký học ít nhất một khóa học về Hoa Kỳ học, ví dụ như lịch sử, văn học, nghệ thuật, hoặc chính 
phủ. Để đảm bảo sinh viên sẽ thành công ở môi trường học thuật Hoa Kỳ, các trường tiếp nhận sẽ hướng dẫn cụ thể và chi tiết về cách nghiên cứu và viết bài luận, tư duy phản biện, quản lý thời gian, cách ghi chép, cách học và làm bài thi. Sinh viên sẽ sống trong ký túc xá cùng sinh viên Hoa Kỳ. Yêu cầu đối với ứng viên tham gia chương trình trao đổi học bổng UGRAD: Là sinh viên đại học chính quy năm thứ nhất, thứ hai và thứ ba (hoặc năm thứ tư đối với sinh viên các trường đại học có hệ đào tạo 5 năm hoặc dài hơn); Còn ít nhất một học kỳ tại Việt Nam sau khi hoàn thành chương trình học tại Hoa Kỳ; Trình độ tiếng Anh giỏi; Có kết quả học tập xuất sắc, điểm trung bình học kỳ gần nhất 7,5 trở lên; Tích cực tham gia các hoạt động cộng đồng và ngoại khoá trong và ngoài nhà trường; Ủu tiên cho những bạn chưa từng hoặc có ít kinh nghiệm tại Hoa Kỳ; Cam kết trở về Việt Nam ngay sau khi kết thúc chương trình.

Bên cạnh những chương trình do Chính phủ trực tiếp tài trợ, những chương trình trao đổi giáo dục đại học do các tổ chức phi chính phủ và các tổ chức giáo dục tiến hành cũng trao học bổng và tạo cơ hội cho nhiều sinh viên Việt Nam tham gia các chương trình học tập tại Hoa Kỳ. Viện Harvard-Yenching thuộc Đại học Harvard là cơ sở đầu tiên thực hiện các chương trình tài trợ cho sinh viên và học giả Việt Nam thực hiện học tập và nghiên cứu ở các trường đại học của Hoa Kỳ (Nguyen T. T., 2015). Các tổ chức phi chính phủ có đóng góp lớn trong việc tài trợ các giảng viên học tập và nghiên cứu tại Hoa Kỳ cũng như tài trợ cho các dự án giáo dục tại Việt Nam có thể kể đến như Quỹ Ford, Quỹ Châu Á. Trong khuôn khổ các chương trình này, các chuyên gia Hoa Kỳ được mời sang giảng dạy tại các trường đại học của Việt Nam, đồng thời các giảng viên của Việt Nam được tuyển chọn cử đi học tập và nghiên cứu tại các trường đại học của Hoa Kỳ. Một số cơ sở giáo dục đại học của Hoa Kỳ có thỏa thuận với Cục Đào tạo với nước ngoài thuộc Bộ Giáo dục và Đào tạo Việt Nam cũng thực hiện những hoạt động hỗ trợ có giá trị lớn nhằm tạo điều kiện cho sinh viên Việt Nam có cơ hội học tập, nghiên cứu tại chính những cơ sở giáo dục đại học này của Hoa Kỳ.

Đến năm 2013, đã có 25 trường đại học của Hoa Kỳ đã trở thành đối tác của Cục Đào tạo với nước ngoài (Cục Hợp tác Quốc tế). Các trường đại học này cung cấp các chương trình đào tạo bậc đại học, phần lớn đào tạo bậc thạc sĩ và bậc tiến sĩ. Trong hợp tác với Cục Đào tạo với nước ngoài của Bộ Giáo dục và đào tạo, các trường đại học này dành những hỗ trợ nhất định đối với sinh viên Việt Nam ví dụ như giảm học phí, thủ tục nhập học thuận lợi, giảm chi phí ăn ở tại trường, cấp học phí, bảo hiểm y tế trong 2 năm đầu với một số chương trình. Đặc biệt với chương trình đào tạo tiến sĩ, nghiên cứu sinh được đảm bảo tham gia các hoạt động giảng dạy và nghiên cứu có thu nhập chi trả sinh hoạt phí. 
Theo tổng hợp của Phòng Văn hóa - Thông tin Hoa Kỳ tại Hà Nội, tính đến năm 2013, đã có trên 3000 học bổng đã trao cho sinh viên, giảng viên, học giả tham gia các chương trình trao đổi giáo dục đại học của Việt Nam và Hoa Kỳ.

Bảng 2.1: Các chương trình trao đổi giáo dục của Hoa Kỳ dành cho Việt Nam (đến tháng 12/2013)

\begin{tabular}{|c|c|}
\hline Các chương trình $(\mathrm{CT})$ & Số lượng \\
\hline CT giảng dạy kinh tế Fulbright & 1130 \\
\hline CT Fulbright cho sinh viên Việt Nam & 487 \\
\hline CT khách thăm quan tự nguyện & 447 \\
\hline CT khách thăm quan quốc tế & 418 \\
\hline Các CT trao đổi khác & 230 \\
\hline CT Fulbright cho học giả Việt Nam & 108 \\
\hline CT của Trung tâm nghiên cứu an ninh Châu Á - Thái Bình dương & 100 \\
\hline CT học bổng tiếng Anh & 85 \\
\hline CT nghiên cứu ở các viện của Mỹ & 53 \\
\hline CT học bổng dành cho giáo viên tiếng Anh & 49 \\
\hline $\mathrm{CT}$ cử nhân toàn cầu & 48 \\
\hline CT của Hội đồng Mỹ dành cho các thủ lĩnh chính trị trẻ & 47 \\
\hline CT nghiên cứudành cho các thủ lĩnh sinh viên & 37 \\
\hline
\end{tabular}




\begin{tabular}{|c|c|}
\hline CT học bổng Hubert Humphrey & 32 \\
\hline CT Thủ lĩnh trẻ Đông Nam Á & 30 \\
\hline Đào tạo kỹ thuật cao cấp & 27 \\
\hline CT cử nhân tiếng Anh & 15 \\
\hline Hội thảo về an ninh Đông Á & 11 \\
\hline CT thỉnh giảng/khách thăm quan văn hóa của Trung tâm Kennedy & 10 \\
\hline CT viết quốc tế & 9 \\
\hline Dự án LENS & 3 \\
\hline CT đối tác thông thái dành cho phụ nữ toàn cầu & 2 \\
\hline CT Fulbright cho học giả Mỹ & 2 \\
\hline CT dạy tiếng Anh & 2 \\
\hline CT học bổng U.S.DA - Cochran & 2 \\
\hline CT giải pháp cộng đồng & 1 \\
\hline CT Fulbright cho học giả Mỹ - ASEAN & 1 \\
\hline CT tiến sỹ khoa học và công nghệ quốc tế & 1 \\
\hline CT viết Iowa & 1 \\
\hline CT học bổng quốc tế của Uỷ ban thương mại liên bang & 1 \\
\hline Tổng cộng & 3.389 \\
\hline
\end{tabular}


Nguồn: Phòng Văn hóa - Thông tin Hoa Kỳ tại Hà Nội. Các chuơng trình trên đây do Đại sứ quán Hoa Kỳ trục tiếp điều hành, không tính các chuoong trình của Qũy Giáo dục Việt Nam (VEF).

\subsubsection{Nhóm Chuyên trách hợp tác giáo dục Việt Nam - Hoa Kỳ}

Nhóm Chuyên trách hợp tác giáo dục Việt Nam - Hoa Kỳ được thành lập tháng 6 năm 2008 theo một biên bản Ghi nhớ giữa Chính phủ Việt Nam và Chính phủ Hoa Kỳ, có nhiệm vụ chuyên trách đưa ra các khuyến nghị về cách thức nhằm tăng cường hợp tác giáo dục đại học giữa hai nước, dựa trên ba nguyên tắc hoạt động chính: (1) Khuyến khích tăng thêm các mối liên kết sâu rộng, các chương trình hợp tác chung giữa các trường đại học Việt Nam và Hoa Kỳ; (2) Tăng số lượng sinh viên Việt Nam sang học tại các cơ sở giáo dục đại học của Hoa Kỳ, đặc biệt là sinh viên theo học các chương trình đào tạo thạc sĩ; (3) Thúc đẩy các chương trình giáo dục được thiết kế nhằm giúp sinh viên Việt Nam đạt được những kĩ năng cần thiết trong quá trình hiện đại hóa nền kinh tế Việt Nam. (U.S. - Vietnam Education Task Force, 2009)

Thành viên của Nhóm Chuyên trách hợp tác giáo dục Việt Nam - Hoa Kỳ bao gồm từ phía Hoa Kỳ: đại diện Hiệp hội các trường đại học của Hoa Kỳ, tập đoàn General Electric, tập đoàn Intel, đại học Johns Hopkins, trường New School, Đại sứ quán Hoa Kỳ tại Việt Nam, Vụ Văn hóa và Giáo dục Hoa Kỳ; phía Việt Nam gồm: Thứ trưởng Bộ Giáo dục và Đào tạo, Vụ trưởng các vụ Giáo dục Đại học, Hợp tác quốc tế thuộc Bộ Giáo dục và Đào tạo, hiệu trưởng Đại học Đà Nẵng và Đại học Cần Thơ.

Sau thời gian làm việc tích cực, Nhóm Chuyên trách hợp tác giáo dục Việt Nam - Hoa Kỳ đưa ra bản báo cáo vào tháng 9 năm 2009, đóng vai trò quan trọng trong quan hệ hợp tác giữa Việt Nam và Hoa Kỳ trên lĩnh vực giáo dục đại học. Về quan hệ hợp tác giáo dục đại học giữa hai nước, bản báo cáo nhận định những bối cảnh rộng lớn hơn để hiểu rõ những khuyến nghị cho hợp tác giáo dục đại học giữa hai nước, bao gồm:

Thứ nhất, Nhóm Chuyên trách nhất trí cao về giá trị của việc tăng cường hợp tác giáo dục đại học giữa sinh viên, giảng viên, các nhà nghiên cứu trên tất cả các bậc học, lĩnh vực học và tất cả cơ sở giáo dục đại học của cả hai nước. Các hoạt động trao đổi giáo dục góp phần tăng cường thành tựu học tập, xây dựng sự hiểu biết lẫn nhau cũng như tình hữu nghị gắn bó lâu dài giữa nhân dân Việt Nam và Hoa Kỳ.

Thứ hai, Nhóm Chuyên trách nhận thấy sự cần thiết phải hiện đại hóa hệ thống giáo dục đại học của Việt Nam, bao gồm những thay đổi cơ bản trong quản trị đại học, sự tự chủ của các cơ sở giáo dục đại học, tài chính và quản lý, tuyển dụng giảng viên, cơ cấu lương 
thưởng cũng như chương trình đào tạo và phương pháp nghiên cứu, giảng dạy, đánh giá. Theo Nhóm Chuyên trách, những thay đổi này không chỉ cần thiết đối với sinh viên, những người cần có kiến thức và kĩ năng tư duy phản biện, phục vụ cho công cuộc hiện đại hóa mà Việt Nam theo đuổi, mà việc cải cách giáo dục một cách cơ bản và hệ thống sẽ tạo môi trường cho sự hợp tác hiệu quả và bền vững giữa các trường đại học và cao đẳng của Việt Nam và Hoa Kỳ.

Thứ ba, chủ thể chính của công tác cải cách, hiện đại hóa giáo dục đại học Việt Nam cũng như hỗ trợ về tài chính cho quá trình này phải là Chính phủ Việt Nam. Nhu cầu cải cách của Việt Nam chắc chắn sẽ nhận được sự cố vấn và hợp tác từ các chuyên gia nước ngoài, trong đó có chuyên gia từ Hoa Kỳ trên các lĩnh vực giáo dục, tuy nhiên chỉ đem lại sự phát triển một cách hệ thống nhất khi có sự hỗ trợ của Chính phủ của cả hai nước.

Thứ tư, các khuyến nghị được đưa ra trong Báo cáo này sẽ đi từ cam kết đến thực hiện hiệu quả hợp tác giáo dục đại học trong môi trường quốc tế cạnh tranh nhờ có nỗ lực của Chính phủ hai phía, đồng thời các cơ sở giáo dục đại học công và các thành phần tư nhân với tính tự chủ cao của Hoa Kỳ, nơi duy trì cung cấp các chuyên gia và nguồn lực cho quan hệ hợp tác giáo dục đại học, sẽ chỉ đầu tư khi thấy sự hợp tác đem lại lợi ích chung cho cả hai bên.

Thứ năm, Nhóm Chuyên trách hiểu rõ con đường phía trước sẽ còn nhiều thách thức, rất cần có sự tham gia của các thành phần chính phủ lẫn phi chính phủ, các ngành, cơ sở trên nhiều lĩnh vực khác nhau; và trên con đường phía trước cần xác định rõ những gì mang tính cấp thiết, những gì cần phải kiên trì, xác định những mong muốn có thể đạt được ngay và những mong muốn cần thời gian lâu dài mới có thể đạt được.

Thứ sáu, các khuyến nghị được đưa ra có liên quan chặt chẽ với nhau, và sự tiến triển của mỗi khuyến nghị đều là yếu tố cần thiết cho sự tiến triển của các khuyến nghị khác. Giáo dục đại học là một hệ thống phức tạp trong bất kỳ xã hội nào, và được hình thành bởi rất nhiều yếu tố liên quan khác trong xã hội.

Đặt ra bối cảnh chung, Nhóm Chuyên trách hợp tác giáo dục Việt Nam - Hoa Kỳ đã đề ra trong bản Báo cáo nội dung chính của những khuyến nghị đối với quan hệ hợp tác giáo dục đại học giữa Việt Nam và Hoa Kỳ. Những khuyến nghị có nội dung cơ bản:

(1) Bước cấp thiết nhất là làm rõ và sắp xếp hợp lý các quy trình cần thiết cho việc hợp tác giữa các cơ sở giáo dục đại học Hoa Kỳ với các cơ sở giáo dục đại học là đối tác của họ tại Việt Nam.

(2) Các cơ sở giáo dục đại học của Việt Nam cần hoạt động một cách tự chủ hơn và có trách nhiệm giải trình lớn hơn nếu tăng cường sự hợp tác với các cơ sở giáo dục đại học 
của Hoa Kỳ, cũng như phát triển một cách hệ thống và lâu dài thông qua các chương trình tiên tiến. Để duy trì sự hợp tác với các cơ sở giáo dục đại học của Hoa Kỳ, các hoạt động hợp tác cần được vận hành một cách minh bạch, linh hoạt hơn và nhận được những hỗ trợ một cách có hệ thống.

(3) Để thu hút các cơ sở giáo dục đại học và các thành phần tư nhân đầu tư vào việc xây dựng thành công một trường đại học mô hình Hoa Kỳ tại Việt Nam, cần phải thể hiện được một triển vọng mang tính thực tế và có thể đem lại lợi ích chung, cũng như cam kết về nguyên tắc quản trị, sự tự chủ, trách nhiệm giải trình, tài chính, hoạt động, đào tạo, chất lượng được xác nhận bởi Nhóm Tư vấn. Cần xác định một hoặc một nhóm các cơ sở giáo dục đại học có vai trò chủ chốt, có tiềm năng xây dựng kế hoạch chiến lược để từng bước đạt được thành tựu và đạt được kết quả mong muốn lâu dài. Nhóm Chuyên trách khuyến nghị bước đầu tiên là cần tập trung xây dựng một trường đại học chuyên về nghiên cứu theo mô hình của Hoa Kỳ nhằm phục vụ cho đối tượng sinh viên bậc đại học.

(4) Việc tăng số lượng nghiên cứu sinh Việt Nam theo học tại Hoa Kỳ yêu cầu phải có sự chuẩn bị kỹ lưỡng hơn từ bậc học đại học và bậc thạc sĩ nhằm giúp cho các ứng cử viên sẽ có quá trình học tập nghiên cứu thành công hơn tại các trường đại học của Hoa Kỳ. Để tạo ra một đội ngũ ứng cử viên xuất sắc trở thành nghiên cứu sinh tại các trường đại học Hoa Kỳ, các chương trình đào tạo thạc sĩ trong nước trước đó cần được phát triển một cách phù hợp. Để thu hút những tiến sĩ được đào tạo ở Hoa Kỳ trở về Việt Nam giảng dạy và nghiên cứu, góp phần phát triển năng lực nghiên cứu và phát triển hệ thống giáo dục đại học trong nước, cần phải có sự đổi mới tạo ra môi trường giảng dạy và nghiên cứu phong phú, cởi mở.

(5) Đảm bảo chất lượng học tập là yếu tố tiên quyết để chính phủ, các quỹ, doanh nghiệp hoặc các nguồn khác quyết định phân bổ nguồn hỗ trợ một cách hợp lý cho các cơ sở giáo dục đại học. Việc thiết lập quy trình độc lập kiểm định chất lượng cơ sở đào tạo, chương trình đào tạo được dựa trên sự đánh giá một cách khách quan, minh bạch của các cơ sở ngang cấp là một bước đi quan trọng trong quá trình tiến tới chất lượng đào tạo được quốc tế công nhận.

(6) Thông qua kế hoạch hiệu quả mang tính quốc gia về việc phát triển kĩ năng ngôn ngữ Anh là một việc cần thiết nếu Việt Nam mong muốn tích cực tham gia vào nền kinh tế toàn cầu, hay thu hút sự đầu tư nước ngoài. Kế hoạch này đòi hỏi có sự hợp tác của các cơ sở giáo dục quốc tế và các thành phần tư nhân.

(7) Các doanh nghiệp và các tổ chức phi lợi nhuận phải tham gia trực tiếp và liên tục nhằm thúc đẩy mạnh mẽ hơn hợp tác giáo dục đại học giữa hai nước. Thường xuyên trao đổi và tương tác giữa các trường đại học Việt Nam với các thành phần tư nhân nước ngoài là 
yếu tố cần thiết để tăng cường lợi ích chung là tạo ra đội ngũ nhân lực có trình độ và những kĩ năng cần thiết để có khả năng tham gia một cách cạnh tranh trong quá trình hiện đại hóa của nền kinh tế Việt Nam.

Trên cơ sở nội dung cơ bản của các khuyến nghị, Nhóm Chuyên trách hợp tác giáo dục Việt Nam - Hoa Kỳ đưa ra những phương thức cụ thể dựa trên ba nguyên tắc hoạt động chính bao gồm: khuyến khích tăng thêm các mối liên kết sâu rộng, các chương trình hợp tác chung giữa các trường đại học Việt Nam và Hoa Kỳ bằng cách xây dựng một lộ trình thích hợp để xây dựng cơ sở giáo dục đại học theo mô hình Hoa Kỳ tại Việt Nam, xây dựng chương trình tiên tiến tại Việt Nam, làm rõ và đơn giản hóa các thủ tục để xây dựng một chương trình giáo dục mới ở Việt Nam; tăng số lượng sinh viên Việt Nam sang học tại các cơ sở giáo dục đại học của Hoa Kỳ, đặc biệt là sinh viên theo học các chương trình đào tạo thạc sĩ thông qua phân tích bối cảnh hợp tác giáo dục đại học Việt Nam - Hoa Kỳ và các hành động cụ thể để đạt được hiệu quả nâng cao số lượng sinh viên trao đổi; thúc đẩy các chương trình giáo dục được thiết kế nhằm giúp sinh viên Việt Nam đạt được những kĩ năng cần thiết trong quá trình hiện đại hóa nền kinh tế Việt Nam thông qua các khuyến nghị cụ thể về nâng cao kiến thức và kĩ năng cơ bản, nâng cao khả năng tiếng Anh, hình thức kiểm tra và công nhận trong giáo dục, mối quan hệ giữa các cơ sở giáo dục công lập và tư nhân.

\subsubsection{Họp tác trong xây dụng mô hình giáo dục đại học ở Việt Nam}

2.2.3.1. Các chuơng trình liên kết đào tạo của co sở giáo dục đại học Việt Nam với co sở giáo dục đại hoc Hoa Kỳ

Theo thống kê của Cục Hợp tác quốc tế, Bộ Giáo dục và Đào tạo, cả nước đến nay đã có hơn 500 chương trình hợp tác và liên kết đào tạo giữa các cơ sở giáo dục đại học Việt Nam thực hiện với hơn 200 cơ sở giáo dục đại học tại 30 quốc gia và vùng lãnh thổ. Các chương trình liên kết đào tạo này được triển khai dưới nhiều hình thức: Đào tạo toàn phần tại Việt Nam hoặc một phần tại Việt Nam và một phần tại nước ngoài; đào tạo theo chương trình của nước ngoài hoặc chương trình do hai trường đối tác cùng xây dựng, hoặc theo hình thức chuyển nhượng "franchising", trong đó cơ sở giáo dục nước ngoài chuyển giao chương trình đào tạo cho cơ sở giáo dục Việt Nam và giám sát điều kiện đảm bảo chất lượng (Cục Hợp tác Quốc tế).

Trong 30 quốc gia thực hiện các chương trình liên kết đào tạo giáo dục đại học với Việt Nam, Hoa Kỳ là quốc gia có số lượng chương trình liên kết lớn nhất. Tính đến năm 2015, có tổng số 444 chương trình liên kết đào tạo giữa cơ sở giáo dục đại học của Việt Nam với nước ngoài, 70 trong số đó là các chương trình liên kết đào tạo giữa cơ sở đại học của Việt Nam với cơ sở giáo dục đại học của Hoa Kỳ. Các chương trình liên kết được thực hiện 
có thể do Bộ Giáo dục và Đào tạo Việt Nam phê duyệt hoặc do các cơ sở giáo dục đại học tự phê duyệt. Theo thống kê của Cục Hợp tác quốc tế, Bộ Giáo dục và Đào tạo, đến năm 2015, có 257 chương trình đã được Bộ Giáo dục và Đào tạo phê duyệt, trong đó 36 chương trình hợp tác với các cơ sở giáo dục đại học của Hoa Kỳ (Cục Hợp tác Quốc tế).

Bảng 2.2: Danh sách các chương trình liên kết đào tạo với Hoa Kỳ đã được Bộ Giáo dục và Đào tạo phê duyệt (2002-2015)

\begin{tabular}{|c|c|c|c|c|}
\hline TT & $\begin{array}{c}\text { Cơ sở giáo dục Việt } \\
\text { Nam }\end{array}$ & Đối tác nước ngoài & Văn bằng & Chuyên ngành \\
\hline 1 & $\begin{array}{c}\text { Học viện Cảnh sát nhân } \\
\text { dân }\end{array}$ & Trường ĐH Maryland & Thạc sĩ & $\begin{array}{c}\text { Lãnh đạo trong lĩnh vực } \\
\text { Tư pháp }\end{array}$ \\
\hline 2 & $\begin{array}{l}\text { Học viện Công nghệ } \\
\text { Bưu chính Viễn thông }\end{array}$ & $\begin{array}{c}\text { Trường ĐH Staten Island } \\
\text { CSI/CUNU }\end{array}$ & Cử nhân & Kỹ thuật máy tính \\
\hline 3 & Học viện Ngân hàng & $\begin{array}{c}\text { Trường ĐH Thành phố } \\
\text { Seattle }\end{array}$ & Cử nhân & $\begin{array}{c}\text { Quản trị Kinh doanh } \\
\text { chuyên ngành Quản trị } \\
\text { Tài chính }\end{array}$ \\
\hline 4 & $\begin{array}{c}\text { Hội Khuyến học Việt } \\
\text { Nam }\end{array}$ & $\begin{array}{l}\text { Trường ĐH Nam } \\
\text { Columbia }\end{array}$ & $\begin{array}{l}\text { Cử nhân } \\
\text { Thạc sĩ } \\
\text { Tiến sĩ }\end{array}$ & Quản trị Kinh doanh \\
\hline 5 & Trường CĐ Viễn Đông & Trường ĐH Valdosta & Cử nhân & Quản trị Kinh doanh \\
\hline 6 & $\begin{array}{c}\text { Trường ĐH Bà Rịa - } \\
\text { Vũng Tàu }\end{array}$ & $\begin{array}{c}\text { Trường ĐH Thành phố } \\
\text { Seattle }\end{array}$ & $\begin{array}{l}\text { Cử nhân } \\
\text { Thạc sĩ }\end{array}$ & Quản trị Kinh doanh \\
\hline \multirow{3}{*}{7} & \multirow{3}{*}{$\begin{array}{c}\text { Trường Đại học Bách } \\
\text { Khoa Hà Nội }\end{array}$} & Trường ĐH Troy & Cử nhân & $\begin{array}{l}\text { Khoa học máy tính } \\
\text { Quản trị Kinh doanh }\end{array}$ \\
\hline & & $\begin{array}{c}\text { Trường ĐH Oklahoma } \\
\text { City }\end{array}$ & Thạc sĩ & Quản trị Kinh doanh \\
\hline & & $\begin{array}{c}\text { Trường ĐH Northcentral } \\
(\mathrm{NCU})\end{array}$ & Cử nhân & Quản trị Kinh doanh \\
\hline 8 & Trường ĐH Bình Dương & Trường ĐH Benedictine & Thạc sĩ & Quản trị Kinh doanh \\
\hline 9 & $\begin{array}{c}\text { Trường ĐH Công nghệ } \\
\text { Sài Gòn }\end{array}$ & Trường ĐH Troy & Cử nhân & $\begin{array}{l}\text { Khoa học máy tính } \\
\text { Quản trị Kinh doanh }\end{array}$ \\
\hline \multirow{3}{*}{10} & \multirow{3}{*}{$\begin{array}{c}\text { Trường ĐH Công nghệ } \\
\text { TP. Hồ Chí Minh }\end{array}$} & Trường ĐH Lincoln & $\begin{array}{l}\text { Cử nhân } \\
\text { Thạc sĩ }\end{array}$ & Quản trị Kinh doanh \\
\hline & & \multirow{2}{*}{ Trường ĐH Bristol } & Cử nhân & Kinh doanh \\
\hline & & & Thạc sĩ & Quản trị kinh doanh \\
\hline
\end{tabular}




\begin{tabular}{|c|c|c|c|c|}
\hline & & Trường ĐH Utica & $\begin{array}{l}\text { Cao đẳng } \\
\text { Cử nhân }\end{array}$ & Quản trị Kinh doanh \\
\hline 11 & $\begin{array}{c}\text { Trường ĐH Công nghiệp } \\
\text { Hà Nội }\end{array}$ & Trường ĐH Frostburg & Cử nhân & Khoa học máy tính \\
\hline 12 & $\begin{array}{c}\text { Trường ĐH Công nghiệp } \\
\text { TP.HCM }\end{array}$ & Trường ĐH Northcentral & Cử nhân & Quản trị kinh doanh \\
\hline & & Trường ĐH Thomas & Cử nhân & Quản trị Kinh doanh \\
\hline 13 & Trường ĐH Cửu Long & $\begin{array}{c}\text { Trường ĐH Bách khoa } \\
\text { Tây Bắc }\end{array}$ & Thạc sĩ & Quản trị Kinh doanh \\
\hline 14 & Trường ĐH Đông Á & Trường ĐH Benedictine & Thạc sĩ & Quản trị kinh doanh \\
\hline \multirow{3}{*}{15} & \multirow{3}{*}{ Trường ĐH Duy Tân } & Trường ĐH Appalachian & Cử nhân & $\begin{array}{l}\text { Quản trị kinh doanh } \\
\text { Kế toán } \\
\text { Khoa học máy tính }\end{array}$ \\
\hline & & Trường ĐH Medaille & Cử nhân & $\begin{array}{c}\text { Quản trị kinh doanh } \\
\text { Kế toán }\end{array}$ \\
\hline & & Trường ĐH Upper Iowa & Cử nhân & $\begin{array}{l}\text { Quản trị kinh doanh, } \\
\text { Quản trị Tài chính, Hệ } \\
\text { thống thông tin và Công } \\
\text { nghệ thông tin }\end{array}$ \\
\hline 16 & $\begin{array}{c}\text { Trường ĐH Giao thông } \\
\text { vận tải TP. HCM }\end{array}$ & $\begin{array}{c}\text { Trường ĐH Bang } \\
\text { Arkansas }\end{array}$ & Cử nhân & $\begin{array}{l}\text { Kỹ thuật xây dựng } \\
\text { Kỹ thuật điện } \\
\text { Kỹ thuật cơ khí }\end{array}$ \\
\hline \multirow[t]{2}{*}{17} & \multirow[t]{2}{*}{$\begin{array}{l}\text { Trường ĐH Kinh tế quốc } \\
\text { dân }\end{array}$} & $\begin{array}{l}\text { Trường ĐH bang } \\
\text { California, San } \\
\text { Bernardino }\end{array}$ & Cử nhân & Quản trị \\
\hline & & Trường ĐH Ohio & Thạc sĩ & Kinh tế tài chính \\
\hline 18 & $\begin{array}{l}\text { Trường ĐH Kinh tế- Tài } \\
\text { chính TP. Hồ Chí Minh }\end{array}$ & $\begin{array}{c}\text { Trường ĐH Missouri-St } \\
\text { Louis }\end{array}$ & Cử nhân & $\begin{array}{l}\text { Quản trị Kinh doanh } \\
\text { Khoa học máy tính }\end{array}$ \\
\hline \multirow[b]{2}{*}{19} & \multirow{2}{*}{$\begin{array}{c}\text { Trường ĐH Kinh tế TP. } \\
\text { Hồ Chí Minh }\end{array}$} & $\begin{array}{c}\text { Trường ĐH Houston } \\
\text { Clear Lake }\end{array}$ & Cử nhân & Kinh tế \\
\hline & & $\begin{array}{l}\text { Trường Quản lý nhà nước } \\
\text { John F. Kennedy, Trường } \\
\text { ĐH Harvard }\end{array}$ & Thạc sĩ & Chính sách công \\
\hline 20 & $\begin{array}{c}\text { Trường ĐH Lương Thế } \\
\text { Vinh }\end{array}$ & Trường ĐH Lincoln & Cử nhân & Quản trị Kinh doanh \\
\hline 21 & Trường ĐH Ngoại & Trường Kinh doanh & Thạc sĩ & Quản trị Kinh doanh \\
\hline
\end{tabular}




\begin{tabular}{|c|c|c|c|c|}
\hline & \multirow[t]{2}{*}{ thương } & $\begin{array}{c}\text { Shidler thuộc Trường ĐH } \\
\text { Hawaii }\end{array}$ & & \\
\hline & & Trường ĐH Minot State & Cử nhân & $\begin{array}{l}\text { Kinh doanh quốc tế } \\
\text { Tài chính }\end{array}$ \\
\hline 22 & $\begin{array}{c}\text { Trường ĐH Quốc tế } \\
\text { Hồng Bàng }\end{array}$ & $\begin{array}{c}\text { Trường ĐH Northern } \\
\text { Colorado }\end{array}$ & Thạc sĩ & Điều dưỡng \\
\hline 23 & $\begin{array}{l}\text { Trường ĐH Sư phạm } \\
\text { TP. Hồ Chí Minh }\end{array}$ & Trường ĐH Houston & Thạc sĩ & $\begin{array}{c}\text { Giáo dục (Chương trình } \\
\text { và phương pháp giảng } \\
\text { dạy) }\end{array}$ \\
\hline 24 & $\begin{array}{c}\text { Trường ĐH Tài chính - } \\
\text { Marketing }\end{array}$ & $\begin{array}{c}\text { Trường ĐH Bách khoa } \\
\text { Tây Bắc }\end{array}$ & Thạc sĩ & Quản trị Kinh doanh \\
\hline 25 & Trường ĐH Thương mại & $\begin{array}{c}\text { Trường ĐH Houston - } \\
\text { Clear Lake }\end{array}$ & Cử nhân & $\begin{array}{c}\text { Tài chính, Quản lý } \\
\text { chăm sóc sức khỏe, } \\
\text { Marketing Kế toán, } \\
\text { Kinh doanh, Quản lý, } \\
\text { Hệ thống thông tin quản } \\
\text { lý }\end{array}$ \\
\hline
\end{tabular}

Nguồn: Cục Họp tác quốc tế, Bộ Giáo dục và Đào tạo

Có thể thấy các chương trình liên kết đào tạo với các cơ sở giáo dục đại học của Hoa Kỳ phần lớn tập trung vào các lĩnh vực kinh tế như ngành quản trị kinh doanh, tài chính, bên cạnh đó là các ngành khoa học máy tính và chính sách công, theo đánh giá của Cục Hợp tác quốc tế Bộ Giáo dục và Đào tạo, về lợi ích quốc gia các chương trình này đã góp phần cung ứng cho xã hội nguồn nhân lực có chất lượng cao, thúc đẩy Việt Nam trên con đường hiện đại hóa nền kinh tế cũng như quá trình hội nhập quốc tế của Việt Nam.

2.2.3.2. Đại học Việt Nam áp dụng giảng dạy các chuơng trình tiên tiến của đại học

\section{Hoa Kỳ}

Dựa trên nhu cầu phát triển nguồn nhân lực có chất lượng để phát triển kinh tế - xã hội trong thời kỳ hội nhập và từ kinh nghiệm của các nước trong khu vực, Việt Nam cần phải xây dựng các trường đại học có chất lượng quốc tế, giải pháp trước mắt là tạo cơ hội cho một số khoa, ngành mạnh trong các trường đại học tiếp cận với trình độ tiên tiến trong khu vực và quốc tế. Một trong những giải pháp để đạt được mục đích trên là áp dụng ngay một số chương trình đào tạo của các trường đại học tiên tiến trên thế giới vào giảng dạy bằng tiếng Anh ở một số trường đại học Việt Nam. Những nhận định trên của Bộ Giáo dục và Đào tạo Việt Nam cho thấy nhu cầu thiết yếu của việc áp dụng các chương trình giáo dục chất lượng quốc tế phù hợp vào môi trường đại học tại Việt Nam. Đồng thời, tình hình thực tế cũng cho 
thấy thấy tại Việt Nam đã xuất hiện nhiều chương trình liên kết giữa các cơ sở giáo dục đại học Việt Nam với các cơ sở giáo dục đại học nước ngoài, tuy đã đạt được nhiều kết quả khách quan nhưng vẫn không đủ để tạo ra những tác động mạnh làm chuyển động toàn hệ thống giáo dục đại học theo hướng đổi mới cơ bản và toàn diện (Bộ Giáo dục và Đào tạo, 2008) do một số nguyên nhân được cho là còn ít về số lượng, các chương trình chưa được mở rộng với quy mô đại trà, chưa có sự phát triển đồng bộ để đạt được hiệu quả lớn nhất trong việc hợp tác với các cơ sở giáo dục đại học nước ngoài. Từ những thực trạng trên, Bộ Giáo dục và Đào tạo Việt Nam xây dựng đề án "Đào tạo theo chương trình tiên tiến tại một số trường đại học Việt Nam giai đoạn 2008 - 2015" với mục tiêu: Triển khai thực hiện một số chương trình tiên tiến đào tạo trình độ đại học nhằm tạo điều kiện để xây dựng và phát triển một số ngành đào tạo, khoa, trường đại học mạnh đạt chuẩn khu vực và đẳng cấp quốc tế; góp phần nâng cao chất lượng và triển khai các chương trình đổi mới cơ bản và toàn diện giáo dục đại học Việt Nam; phấn đấu đến năm 2020 có một số trường đại học của Việt Nam được xếp hạng trong số 200 trường đại học hàng đầu thế giới (Bộ Giáo dục và Đào tạo, 2008).

Đề án được Chính phủ phê duyệt vào tháng 10 năm 2008, là cơ sở để hơn 20 trường đại học tại Việt Nam áp dụng các chương trình giảng dạy tiên tiến từ các trường đại học tại nước ngoài, trong đó phần lớn các chương trình thí điểm đầu tiên áp dụng mô hình tiên tiến của đối tác là các trường đại học của Hoa Kỳ.

Dựa theo tiêu chí được xác định trong đề án, các chương trình giảng dạy tiên tiến được các trường đại học Việt Nam áp dụng đều là chương trình từ những trường đại học chất lượng của Hoa Kỳ, với yêu cầu phải thuộc nhóm 200 trường đại học hàng đầu thế giới trong bảng xếp hạng của các hiệp hội, tổ chức kiểm định giáo dục cấp quốc gia hoặc quốc tế (Bộ Giáo dục và Đào tạo, 2008). Khác với các chương trình chất lượng cao và liên kết, các chương trình giảng dạy tiên tiến bao gồm cả quy trình, kế hoạch đào tạo, quy định học vụ, quản lý đào tạo được thiết kế bởi các cơ sở giáo dục đại học Hoa Kỳ và thực hiện giảng dạy bằng tiếng Anh.

Từ năm 2006, Bộ Giáo dục và Đào tạo bắt đầu triển khai thí điểm các chương trình tiên tiến. Theo thống kê của Nhóm Chuyên trách hợp tác giáo dục Việt Nam - Hoa Kỳ, các trường đại học Việt Nam ký cam kết với các trường đại học của Hoa Kỳ về sử dụng chương trình đào tạo, tập huấn cho giảng viên và cán bộ quản lý, tư vấn xây dựng cơ sở vật chất, cử các giảng viên Hoa Kỳ sang Việt Nam giảng dạy và giúp kiểm định chất lượng.

\section{Bảng 2.3: Các trường đại học của Việt Nam hợp tác với các trường đại học của} Hoa Kỳ về áp dụng giảng dạy chương trình tiên tiến 


\begin{tabular}{|c|c|c|c|}
\hline TT & $\begin{array}{c}\text { Tên trường đại học của Việt } \\
\text { Nam }\end{array}$ & Đối tác Hoa Kỳ & Ngành đào tạo \\
\hline 1 & $\begin{array}{l}\text { ĐH Khoa học tự nhiên, } \\
\text { ĐHQG Hà Nội }\end{array}$ & $\begin{array}{c}\text { ĐH Illinois tại Urbana - } \\
\text { Champaign }\end{array}$ & Hóa học \\
\hline 2 & $\begin{array}{l}\text { ĐH Khoa học tự nhiên, } \\
\text { ĐHQG Hà Nội }\end{array}$ & $\begin{array}{c}\text { ĐH Washington, Bang } \\
\text { Washington }\end{array}$ & Toán \\
\hline 3 & $\begin{array}{l}\text { ĐH Khoa học tự nhiên, } \\
\text { ĐHQG TP.Hồ Chí Minh }\end{array}$ & ĐH Bang Portland, Oregon & Khoa học máy tính \\
\hline 4 & $\begin{array}{c}\text { ĐH Bách Khoa, ĐHQG } \\
\text { TP.Hồ Chí Minh }\end{array}$ & $\begin{array}{c}\text { ĐH Illinois tại Urbana - } \\
\text { Champaign }\end{array}$ & Kỹ thuật điện và máy tính \\
\hline 5 & $\begin{array}{c}\text { ĐH Công nghệ thông tin, } \\
\text { ĐHQG TP.HCM }\end{array}$ & ĐH bang Oklahoma & Hệ thống thông tin \\
\hline 6 & Đai học Cần Thơ & ĐH Bang Michigan & $\begin{array}{l}\text { Hóa sinh và sinh học phân } \\
\text { tử/công nghệ sinh học }\end{array}$ \\
\hline 7 & Đai học Cần Thơ & ĐH Auburn, Bang Alabama & Nuôi trồng thủy sản \\
\hline 8 & Đai học Huế & ĐH Virginia & Vật lý \\
\hline 9 & Đai học Đà Nẵng & $\begin{array}{c}\text { ĐH Washington, Bang } \\
\text { Washington }\end{array}$ & Kỹ thuật điện tử \\
\hline 10 & Đai học Đà Nẵng & $\begin{array}{c}\text { ĐH Washington, Bang } \\
\text { Washington }\end{array}$ & Hệ thống nhúng \\
\hline 11 & Đại học Thái Nguyên & ĐH Bang New York tại Buffalo & Kỹ thuật Cơ khí \\
\hline 12 & Đại học Kinh tế Quốc Dân & $\begin{array}{c}\text { ĐH Bang California - Long } \\
\text { Beach }\end{array}$ & Tài chính \\
\hline 13 & Đại học Bách Khoa Hà Nội & ĐH Bang California, Chico & Kỹ thuật Cơ khí \\
\hline 14 & Đại học Bách Khoa Hà Nội & $\begin{array}{c}\text { ĐH Illinois tại Urbana - } \\
\text { Champaign }\end{array}$ & Kỹ thuật và Khoa học vật liệu \\
\hline 15 & Đại học Bách Khoa Hà Nội & ĐH Duke- Durham & Kỹ thuật hệ thống Y sinh \\
\hline 16 & Đại học Nông nghiệp Hà Nội & ĐH California - Davis & Khoa học cây trồng \\
\hline 17 & Đại học Nông nghiệp Hà Nội & ĐH Wisconsin - Madison & $\begin{array}{c}\text { Quản lí kinh doanh nông } \\
\text { nghiệp }\end{array}$ \\
\hline
\end{tabular}




\begin{tabular}{|c|c|c|c|}
\hline 18 & $\begin{array}{c}\text { ĐH Nông Lâm TP. Hồ Chí } \\
\text { Minh }\end{array}$ & ĐH California - Davis & $\begin{array}{c}\text { Khoa học và Công nghệ Thực } \\
\text { phẩm }\end{array}$ \\
\hline 19 & Đại học Thủy lợi & ĐH Bang Colorado & Kỹ thuật nguồn nước \\
\hline 20 & Đại học Ngoại thương & ĐH Bang Colorado & Kinh tế Quốc tế \\
\hline
\end{tabular}

Nguồn: U.S. - Vietnam Education Task Ford

Tại Hội nghị Tổng kết đào tạo theo chương trình tiên tiến giai đoạn 2006-2016, Bộ Giáo dục và Đào tạo nhận định đào tạo theo chương trình tiên tiến có tác động tích cực đến các hoạt động của trường đại học (QN, 2016).

\subsubsection{Dư án HEEAP}

Năm 2010, Intel - một trong những tập đoàn công nghệ lớn nhất thế giới có trụ sở chính ở thung lũng Silicon, Hoa Kỳ - mở một nhà máy lắp và kiểm nghiệm sản phẩm ở Thành phố Hồ Chí Minh. Tuy nhiên gặp vấn đề với việc tuyển dụng nguồn nhân lực đáp ứng được yêu cầu, Intel đã tiến hành khảo sát điều tra chất lượng tân kỹ sư tại các trường đại học kỹ thuật Việt Nam. Kết quả cho thấy hầu hết tân kỹ sư ở Việt Nam có kiến thức lý thuyết bài bản nhưng lại thiếu một số kỹ năng cần thiết như sử dụng tiếng Anh, kỹ năng làm việc nhóm, kỹ năng thuyết trình, kỹ năng tư duy phản biện, giải quyết vấn đề và kỹ năng lãnh đạo để có thể làm việc một cách hiệu quả trong môi trường thực tế. Nhận thấy nhu cầu cấp thiết về nguồn nhân lực chất lượng cao, cũng như thấy được tinh thần thiện chí, khuyến khích đầu tư nước ngoài trong lĩnh vực giáo dục đại học của Chính phủ Việt Nam, tập đoàn Intel quyết định tài trợ thiết lập một dự án giáo dục tại Việt Nam, với mục đích ban đầu là cải thiện phương pháp học tập mang tính thực tế tích cực hơn cho Việt Nam. Dự án Liên minh giáo dục đại học ngành kỹ thuật (HEEAP) của Trường Kỹ thuật Ira A. Fulton thuộc Đại học bang Arizona (ASU), Hoa Kỳ chính thức được thành lập tại Việt Nam dưới sự hợp tác cùng với tập đoàn Intel và Cơ quan Phát triển Quốc tế Hoa Kỳ (USAID). Đồng thời, dự án nhận được sự tài trợ từ các đơn vị Bộ Giáo dục Việt Nam, Khu Công nghệ cao TP. Hồ Chí Minh, Siemens, Danaher, Cadence, National Instruments và Pearson, thực hiện kết hợp với các trường đại học và cao đẳng kỹ thuật hàng đầu tại Việt Nam.

Với mục tiêu định hướng các chương trình đào tạo nhằm nâng cao chất lượng đầu ra sinh viên, đảm bảo sinh viên ra trường đạt được kiến thức và kỹ năng cần thiết theo yêu cầu của môi trường làm việc, dự án tập trung cải thiện, chuyển đổi và hiện đại hóa các chương trình đại học và dạy nghề về kỹ thuật hàng đầu Việt Nam, theo các phương hướng hoạt động chính:

Thứ nhất là hiện đại hóa chương trình và phương pháp giảng dạy các ngành kỹ thuật ở Việt Nam, bằng cách tạo cơ hội cho các giảng viên Việt Nam đến Hoa Kỳ học tập nâng cao 
kiến thức cũng như các phương pháp giáo dục, từ đó giúp cải thiện các phương pháp giảng dạy ứng dụng và xây dựng lại các chương trình đào tạo tại đại học Việt Nam đạt tiêu chuẩn của $\mathrm{ABET}$ - hiệp hội kiểm định chính cho các chương trình kỹ thuật trên toàn thế giới.

Thứ hai là hiện đại hóa các phòng thí nghiệm, thực hành để sinh viên có thể áp dụng ngay những kiến thức được dạy.

Thứ ba là tạo điều kiện cho các chương trình dạy học bằng tiếng Anh để xây dựng kĩ năng tiếng Anh cho sinh viên trong môi trường công việc sau này, đồng thời hạn chế phải dịch các bản hướng dẫn sang tiếng Việt.

Thứ tư là thiết kế các khóa trao đổi, hướng dẫn những người đứng đầu các trường đại học về công nghệ và kỹ thuật của Việt Nam, nhằm giúp họ có tầm nhìn và chiến lược tốt hơn cho tương lai.

Và thứ năm, thúc đẩy sự đa dạng trong các chương trình nhằm chống lại một thực tế rằng phụ nữ đang không nhận được nhiều ủng hộ khi tham gia vào các ngành nghiên cứu kỹ thuật và dạy nghề tại Việt Nam.

Từ phương hướng trên, dự án đã triển khai một số hoạt động đem lại hiệu quả tích cực trong sự hợp tác nâng cao chất lượng giáo dục ngành công nghệ kỹ thuật cho đại học Việt Nam:

Tạo cho các giảng viên Việt Nam cơ hội tham gia khóa học kéo dài sáu tuần tại Đại học bang Arizona và một tuần tham gia khóa huấn luyện trong nước về phương pháp giảng dạy tích cực. Bên cạnh các chương trình học chính được giảng dạy bởi các giảng viên của Đại học bang Arizona, các chuyên gia và các nhà lãnh đạo hàng đầu của các tập đoàn công nghiệp sẽ được mời để tổ chức các buổi giảng và hội thảo. Các giảng viên nhận được cơ hội này có nhiệm vụ áp dụng các phương pháp giảng dạy tích cực này một cách linh hoạt vào chương trình đại học thực tế ở Việt Nam, đồng thời truyền đạt kiến thức và chia sẻ kinh nghiệm giảng dạy với các đồng nghiệp thông qua các buổi hội thảo.

Tổ chức hội thảo huấn luyện giảng viên trong nước cho khoảng gần 100 giảng viên mỗi năm. Hội thảo được tổ chức theo nhiều chủ đề khác nhau, phù hợp với nhu cầu thực tế của các khoa, trường đang giảng dạy.

Tổ chức các hội thảo về kĩ năng lãnh đạo nhằm mục tiêu thay đổi tư duy và nâng cao kỹ năng quản lý cho các nhà lãnh đạo cấp trung và cao cấp của các trường đại học.

Ngày 20 tháng 8 năm 2012, Bộ Giáo dục và Đào tạo Việt Nam và trường Đại học bang Arizona ký kết bản thỏa thuận đầu tư mở rộng dự án HEEAP nhằm tập trung đào tạo giảng viên cho các trường đại học kỹ thuật Việt Nam. Dự án mở rộng thành sáu chương trình chính bao gồm phát triển lãnh đạo; phát triển giảng viên; chương trình học, phòng thí nghiệm 
và cơ sở hạ tầng; giáo dục từ xa; đa dạng và phát triển chuyên môn giảng dạy; và tiếng Anh, mang lại lợi ích cho thêm khoảng 1000 giảng viên và thu hút thêm 12 đối tác tham gia mở rộng dự án.

\section{Tiểu kết chương 2}

Dưới các nhân tố ngoại sinh là bối cảnh thế giới với xu thế hội nhập, toàn cầu hóa và nhân tố nội sinh gồm quan hệ chính trị, ngoại giao giữa Việt Nam - Hoa Kỳ và nhu cầu hai nước về hợp tác giáo dục đại học đều có tác động thúc đẩy quan hệ hợp tác Việt Nam - Hoa Kỳ trong lĩnh vực giáo dục đại học từ năm 1992 đến năm 2015, các hoạt động hợp tác giáo dục đại học giữa hai nước được thực hiện qua nhiều chương trình hợp tác với các hình thức, nội dung, quy mô đa dạng, nhìn chung các hoạt động hợp tác được khái quát thành:

Thứ nhất là các chương trình trao đổi giáo dục đại học, tiêu biểu là Chương trình Fulbright, Chương trình Quỹ giáo dục Việt Nam, bên cạnh đó là các chương trình học bổng khác như Hubert Humphrey, UGRAD, học bổng của viện Harvard Yenching.

Thứ hai là hoạt động của Nhóm Chuyên trách hợp tác giáo dục Việt Nam - Hoa Kỳvới bản báo cáo quan trọng đưa ra những khuyến nghị cho quan hệ hợp tác giáo dục đại học của hai nước.

Thứ ba là hoạt động hợp tác trong xây dựng mô hình giáo dục đại học ở Việt Nam bao gồm: các chương trình liên kết đào tạo của cơ sở giáo dục đại học Việt Nam với cơ sở giáo dục đại học của Hoa Kỳ; Việt Nam áp dụng giảng dạy các chương trình tiên tiến của cơ sở giáo dục đại học Hoa Kỳ; dự án HEEAP - tiêu biểu cho hoạt động hợp tác xây dựng mô hình giáo dục đại học ở Việt Nam. 


\section{CHUOONG 3}

\section{NHẬN XÉT VÀ MỘT SỐ KIẾN NGHỊ CHO QUAN HỆ HỢP TÁC VIẸTT NAM - HOA KỲ TRONG LĨNH VỤ̉C GIÁO DỤC ĐẠI HỌC}

\subsection{Nhận xét, đánh giá hiệu quả các hoạt động hợp tác Việt Nam - Hoa Kỳ trong}

lĩnh vụ̣c giáo dục đại học

\subsubsection{Nhũ̃ng thành tụu đạt đưọcc}

Những bước đầu hợp tác trong lĩnh vực giáo dục đại học giữa Việt Nam và Hoa Kỳ bắt đầu từ trước khi hai nước bình thường hóa quan hệ ngoại giao. Tiến triển trong hơn 20 năm sau khi chính thức bình thường hóa quan hệ, hợp tác trong lĩnh vực giáo dục đại học đã đạt được những thành tựu nhất định trong quan hệ giữa hai nước.

Thứ nhất là số lượng các chương trình trao đổi giáo dục đại học Việt Nam - Hoa Kỳ ngày càng phong phú đa dạng cũng như đảm bảo về chất lượng chương trình, sự hỗ trợ từ Chính phủ và các tổ chức giáo dục, phi chính phủ thông qua các chương trình học bổng đã tạo điều kiện cho thêm rất nhiều sinh viên Việt Nam và Hoa Kỳ được tham gia vào các chương trình trao đổi giáo dục đại học tại hai nước.

Chương trình Fulbright được bắt đầu tại Việt Nam từ năm 1992, mỗi năm đưa 25-30 sinh viên Việt Nam sang Hoa Kỳ học chương trình thạc sĩ, và 10 học giả sang nghiên cứu tại các trường đại học của Hoa Kỳ. Tính đến năm 2015, 520 sinh viên Việt Nam thông qua Chương trình trao đổi sinh viên của Fulbright đã được theo học chương trình thạc sĩ tại Hoa Kỳ, 118 học giả là các giảng viên, chuyên gia từ Việt Nam thông qua Chương trình học giả có cơ hội học tập, nghiên cứu tại các trường đại học của Hoa Kỳ (U.S. Embassy \& Consulate in Vietnam). Và trong số những ứng viên tài năng trở về từ chương trình Fulbright đã trở thành những con người thành công, đóng góp nhiều công sức cho quá trình xây dựng, phát triển nền kinh tế hiện đại hóa của Việt Nam. Có thể kể đến cựu thành viên viên nổi bật của chương trình Fulbright như Phó thủ tướng kiêm Bộ trưởng Bộ Ngoại giao Phạm Bình Minh thuộc khóa sinh viên đầu tiên theo học tại Hoa Kỳ dưới sự tài trợ của học bổng Fulbright. Những cựu sinh viên khác cũng đều có những đóng góp quan trọng trong lĩnh vực khoa học, kinh tế, học thuật và nghệ thuật. Cựu sinh viên chương trình Fulbright năm 1994, bà Đàm Bích Thủy làm việc tại ngân hàng ANZ ở Singapore từ năm 1995, sau đó được bổ nhiệm làm Tổng giám đốc ANZ Việt Nam vào năm 2005, là người Việt Nam đầu tiên lãnh đạo hoạt động của một ngân hàng quốc tế trong nước, bà được đánh giá cao bởi những đóng góp cho ngành tài chính ngân hàng nước nhà. Đỗ Minh Thùy là cựu sinh viên năm 2004 của học bổng Fulbright đã có cơ hội học tập và nghiên cứu về lĩnh vực báo chí tại Hoa Kỳ, sau khi hoàn thành chương trình học bổng, bà đã có những đóng góp quan trọng cho cộng đồng thông qua 
dự án "Nâng cao năng lực dành cho nhà báo trẻ”, dự án đến năm 2012 đã thu hút hơn 2000 thành viên tham gia tại Hà Nội và Thành phố Hồ Chí Minh.

Chương trình học bổng của Quỹ Giáo dục Việt Nam hoạt động từ năm 2003, tính đến năm 2015 cũng đã hỡ trợ 547 nghiên cứu sinh Việt Nam theo học các chương trình sau đại học tại 99 trường đại học uy tín của Hoa Kỳ. Theo số liệu đến tháng 11 năm 2015, 337 nghiên cứu sinh đã tốt nghiệp với 238 người đã nhận bằng tiến sĩ, 99 người nhận bằng thạc sĩ. Đồng thời trong 337 nghiên cứu sinh đã tốt nghiệp đó, 47 nghiên cứu sinh tiếp tục tham gia chương trình đào tạo tại Hoa Kỳ trước khi trở về Việt Nam, còn 290 người đã hoàn thành chương trình dưới sự hỗ trợ của Quỹ Giáo dục Việt Nam.

Theo thống kê của Quỹ giáo dục Việt Nam, trong 290 người đã hoàn thành chương trình, 233 người $(80 \%)$ đang làm việc tại các khối ngành khác nhau, 28 người $(10 \%)$ vừa trở về Việt Nam và đang tìm kiếm cơ hội việc làm, 22 người $(8 \%)$ học tiếp chương trình tiến sĩ với nguồn tài trợ khác, 7 người $(2 \%)$ đang ở Hoa Kỳ theo các dạng thị thực khác nhau.

Tháng 11 năm 2015, có 186 nghiên cứu sinh đang học tập tại Hoa Kỳ theo học bổng của Quỹ Giáo dục Việt Nam, trong đó: $87 \%$ theo học chương trình tiến sĩ, 13\% theo học chương trình thạc sĩ; $41 \%$ theo học các chuyên ngành kỹ thuật, $23 \%$ theo học chuyên ngành sinh học và khoa học y sinh, 15\% theo học chuyên ngành khoa học máy tính, 7\% theo học chuyên ngành về nông nghiệp, $5 \%$ theo học các chuyên ngành về khoa học vật chất (thiên văn học, hóa học và vật lý), $3 \%$ theo học các chuyên ngành về toán, $3 \%$ theo học chuyên ngành y tế công cộng, $2 \%$ theo học chuyên ngành tài nguyên thiên nhiên, và $1 \%$ theo học nghiên cứu đa ngành.

Bắt đầu từ năm 2007, Chương trình Học giả của Quỹ Giáo dục Việt Nam đã hỗ trợ 50 tiến sĩ của Việt Nam tham gia các chương trình sau tiến sĩ kéo dài từ 5 tới 12 tháng tại 38 trường đại học danh tiếng của Hoa Kỳ.

Theo số liệu thống kê của Đại sứ quán Hoa Kỳ tại Việt Nam, đến năm 2010, Đoàn Ngoại giao Hoa Kỳ đã trao gần 1000 học bổng với tổng ngân sách lên đến 75 triệu đô la.

Biểu đồ 3.1: Tỉ lệ các chương trình học bổng của Chính phủ Hoa Kỳ dành cho sinh viên Việt Nam (1992-2010) 


\section{Học bổng của Chính phủ Hoa Kỳ}

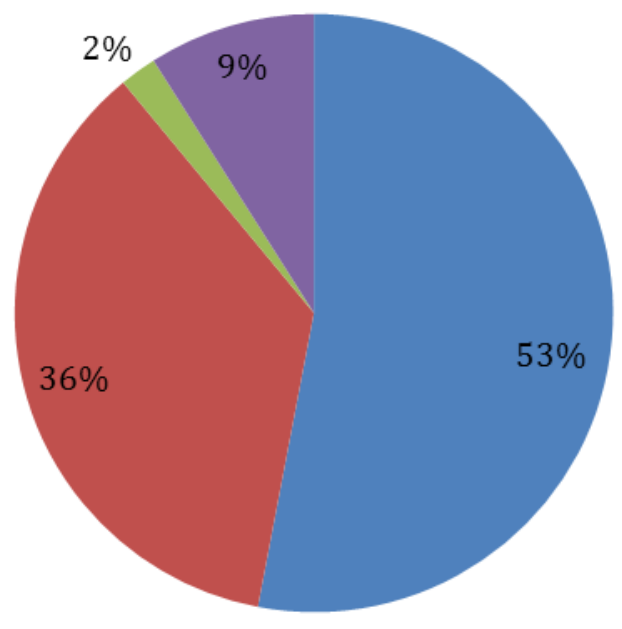

- Học bổng Fulbright

- Quỹ giáo dục Việt Nam

Chương trình Hubert Humphrey

- Các chương trình khác

Nguồn: Phòng Thông tin - Văn hóa (PAS) Đại sứ quán Hoa Kỳ

Các chương trình học bổng cũng như sự hỗ trợ khác từ Chính phủ hai nước, từ các tổ chức giáo dục, tổ chức phi chính phủ đã tạo sự khuyến khích cho nhiều sinh viên Việt Nam tham gia các chương trình trao đổi, và cả du học tự túc. Có thể thấy từ năm 1995 đến 2015, số lượng sinh viên Việt Nam du học tại Hoa Kỳ tăng rõ rệt. Từ khoảng 800 sinh viên vào thời điểm bình thường hóa quan hệ ngoại giao giữa hai nước lên đến con số 18000 sinh viên vào năm 2015, đưa Việt Nam trở thành quốc gia đứng đầu ASEAN và đứng thứ 8 trên thế giới về số lượng sinh viên theo học tại Hoa Kỳ.

Bảng 3.1: Số lượng sinh viên Việt Nam du học tại Hoa Kỳ (1998-2015)

\begin{tabular}{|c|c|c|}
\hline Năm học & $\begin{array}{c}\text { Sinh viên Việt Nam } \\
\text { du học tại Hoa Kỳ }\end{array}$ & Thay đổi so với năm học trước \\
\hline $2014-2015$ & 18,722 & $12.9 \%$ \\
\hline $2013-2014$ & 16,579 & $3.0 \%$ \\
\hline $2012-2013$ & 16,098 & $3.4 \%$ \\
\hline $2011-2012$ & 15,572 & $4.6 \%$ \\
\hline $2010-2011$ & 14,888 & $13.5 \%$ \\
\hline $2009-2010$ & 13,112 & $2.3 \%$ \\
\hline $2008-2009$ & 12,823 & $46.2 \%$ \\
\hline
\end{tabular}




\begin{tabular}{|c|c|c|}
\hline $2007-2008$ & 8,769 & $45.3 \%$ \\
\hline $2006-2007$ & 6,036 & $31.3 \%$ \\
\hline $2005-2006$ & 4,597 & $25.3 \%$ \\
\hline $2004-2005$ & 3,670 & $16.0 \%$ \\
\hline $2003-2004$ & 3,165 & $16.3 \%$ \\
\hline $2002-2003$ & 2,722 & $7.5 \%$ \\
\hline $2001-2002$ & 2,531 & $25.2 \%$ \\
\hline $2000-2001$ & 2,022 & $-10.8 \%$ \\
\hline $1999-2000$ & 2,266 & $42.8 \%$ \\
\hline $1998-1999$ & 1,587 & - \\
\hline
\end{tabular}

Nguồn: Báo cáo Open Door của Viện Giáo dục Quốc tế (IIE)

Thứ hai, các hoạt động hợp tác giáo dục đại học giữa Việt Nam và Hoa Kỳ đã mang lại những lợi ích cho Việt Nam, đặc biệt trong công cuộc xây dựng, đổi mới đất nước. Nếu như chương trình học bổng Fulbright tập trung vào các ngành khoa học xã hội, cho người học những trải nghiệm mạnh mẽ trong chương trình học mang tính hệ thống và kết nối toàn cầu, tạo những bài học kinh nghiệm cho cựu sinh viên trở về Việt Nam xây dựng và phát triển xã hội, thì chương trình học bổng của Quỹ Giáo dục Việt Nam ưu tiên các chuyên ngành toán, khoa học, y tế, kỹ thuật, máy tính hay các ngành khoa học nông nghiệp, công nghệ hạt nhân nhằm đáp ứng nhu cầu của Việt Nam trong phát triển kinh tế theo hướng công nghiệp hóa, hiện đại hóa. Bên cạnh đó các chuyên gia, giáo sư của Hoa Kỳ cùng các thành viên Việt Nam của Nhóm Chuyên trách Hợp tác Giáo dục Việt Nam - Hoa Kỳ đã hỗ trợ Việt Nam thông qua các báo cáo quan trọng nhằm phát triển chất lượng giáo dục đại học tại Việt Nam cũng như hỗ trợ định hướng, khuyến nghị Việt Nam trong việc phát triển, phân bổ các chuyên ngành giáo dục đại học cho phù hợp với nhu cầu thực tại của Việt Nam.

Cũng như các chương trình hỗ trợ học bổng, các chương trình đào tạo liên kết và đào tạo theo chương trình tiên tiến của các trường đại học Hoa Kỳ đã tạo cơ hội cho cả sinh viên, giảng viên, các nhà lãnh đạo trong lĩnh vực giáo dục ở Việt Nam được tiếp cận với chất lượng giáo dục đại học tiên tiến mang đẳng cấp thế giới, đây cũng là cơ hội để Việt Nam học hỏi, phát triển tiềm năng để có thể xây dựng các chương trình giáo dục đại học đạt tiêu chuẩn quốc tế cao trong tương lai không xa. Một trong những chương trình liên kết giáo dục đại học nổi bật là giữa Việt Nam và Hoa Kỳ là trường Đại học Hawaii tại Manoa đã ký kết văn bản ghi nhớ với Đại học Quốc gia Hà Nội, Đại học Thái Nguyên và Đại học Sư phạm Thành phố 
Hồ Chí Minh, thiết lập các chương trình đào tạo thạc sĩ và tiến sĩ. Sinh viên được học tại Việt Nam và nhận bằng của Đại học Hawaii tại Manoa. Theo nhận xét của Hiệu trưởng trường Đại học Hawaii tại Manoa - ông Donald Young, sinh viên Việt Nam thể hiện rất tốt trong quá trình học tập, do đó trường rất mong muốn được đầu tư liên kết với các trường đại học của Việt Nam, trong chương trình liên kết với Đại học Sư phạm Thành phố Hồ Chí Minh đào tạo thạc sĩ và tiến sĩ, nhiều sinh viên đầu ra xuất sắc đã trở thành những nhà quản lý giáo dục, có đóng góp tích cực cho sự phát triển của giáo dục Việt Nam. Một trong những trường đại học công lập của Hoa Kỳ là Đại học Portland cũng mong muốn tăng cường hợp tác liên kết với các trường đại học Việt Nam, bên cạnh hỗ trợ học bổng cho sinh viên Việt Nam theo học tại Đại học Portland ở Hoa Kỳ, trường đại học này còn thúc đẩy liên kết với đại học Việt Nam tiến hành các dự án nghiên cứu chung trong các lĩnh vực xử lý khủng hoảng, phát triển bền vững, biến đổi khí hậu, quản trị công và quản trị doanh nghiệp. Tính đến năm 2015, đã có gần 30 trường đại học của Việt Nam liên kết với các trường đại học của Hoa Kỳ, chú trọng các chuyên ngành kinh tế, thương mại và quản trị. Trong Hội nghị tổng kết đào tạo theo chương trình tiên tiến giai đoạn 2006-2016 do Bộ Giáo dục và Đào tạo tổ chức, theo nhận định của Bộ Giáo dục và Đào tạo, chương trình tiên tiến được xây dựng theo mô hình của đại học nước ngoài như Hoa Kỳ “đã có tác động khá toàn diện đến các hoạt động của các trường triển khai theo hướng chuẩn hoá, hiện đại hoá và hội nhập quốc tế, như các việc: phát triển đội ngũ giảng viên và cán bộ quản lý; cách thức phát triển chương trình đào tạo và cơ sở vật chất; tổ chức và quản lý đào tạo; phương pháp dạy - học và đánh giá; gắn đào tạo với nghiên cứu khoa học và việc làm; xác lập mô hình quản trị và quản lý tự chủ trong trường đại học; xác định chi phí đơn vị tương xứng với chất lượng đào tạo; mở rộng quan hệ hợp tác quốc tế."

Đồng thời, hợp tác với Hoa Kỳ ở lĩnh vực giáo dục đại học tạo cho Việt Nam cơ hội nâng cao chất lượng nguồn nhân lực thông qua các chương trình học thuật, thực hành theo mô hình của các trường đại học, doanh nghiệp Hoa Kỳ. Có thể thấy thành tựu của dự án HEEAP trong sự cải tiến trong chương trình giảng dạy của các giảng viên các trường đại học, cao đẳng, dạy nghề về lĩnh vực công nghệ, kỹ thuật tại Việt Nam, bên cạnh cung cấp lý thuyết đã nâng cao nhiều phương pháp giảng dạy mang tính thực tế và ứng dụng cao, đồng thời chú trọng nâng cao trình độ tiếng Anh cho người học nhằm đảm bảo đầu ra của sinh viên đạt được tiêu chuẩn của các nhà tuyển dụng cả trong và ngoài nước. "Sự hợp tác này là công cụ thúc đẩy mục tiêu của chúng tôi” - nhận xét của Thứ trưởng Bộ Giáo dục và Đào tạo Nguyễn Vinh Hiển đối với chương trình. 
Thứ ba, đối với Hoa Kỳ, các chương trình trao đổi giáo dục đại học với Việt Nam tạo cơ hội để sinh viên, giảng viên, giáo sư Hoa Kỳ đến Việt Nam học tập và nghiên cứu. Các chương trình do Chính phủ hỗ trợ như Fulbright mỗi năm đưa 10 sinh viên, 10 học giả, 15 trợ giảng tiếng Anh và 5-10 chuyên gia cao cấp sang Việt Nam học tập, nghiên cứu, giảng dạy và giúp Việt Nam xây dựng các dự án cải thiện chất lượng giảng dạy và quản lý giáo dục của Việt Nam. Bên cạnh đó, nhiều giảng viên, chuyên gia Hoa Kỳ tham gia nghiên cứu, giảng dạy tại Việt Nam thông qua các chương trình liên kết với các trường đại học của Việt Nam. Mặc dù Việt Nam chưa tạo ra được nhiều chương trình hỗ trợ học bổng cho sinh viên Hoa Kỳ, nhưng Chính phủ và các cơ quan cũng như các trường đại học và cả người dân Việt Nam luôn tạo cơ hội, tiếp đón thân tình các sinh viên Hoa Kỳ tham gia các chương trình trao đổi, nghiên cứu tại Việt Nam.

Với Hoa Kỳ, các hoạt động hợp tác giáo dục đại học với Việt Nam đồng thời là một trong những cơ hội để nhân dân Việt Nam hiểu hơn về Hoa Kỳ, bỏ qua những ký ức thù địch trong quá khứ. Tạo cơ hội cho các sinh viên, học viên tham gia các chương trình trao đổi, theo học tại Hoa Kỳ là tạo cơ hội để Hoa Kỳ thể hiện những nét đặc trưng của mình với sinh viên, sau đó khi sinh viên trở về Việt Nam sẽ có những chia sẻ, truyền đạt với nhân dân, đặc biệt là những bạn trẻ Việt Nam về Hoa Kỳ, thúc đẩy sự mong muốn khám phá theo đuổi "giấc mơ Hoa Kỳ”. Với mong muốn "tăng cường sự hiểu biết lẫn nhau và mối quan hệ thân thiện, hòa bình giữa nhân dân Hoa Kỳ và nhân dân các quốc gia khác”, Hoa Kỳ đã phần nào đạt được điều này đối với nhân dân Việt Nam thông qua các hoạt động hợp tác giáo dục giữa hai nước. Như trong phát biểu của cựu Ngoại trưởng Hillary Clinton tại Lễ kỷ niệm 20 năm chương trình Fulbright Việt Nam tổ chức tại Đại học Ngoại thương năm 2012, bà nhận xét “Thật không quá khi nói rằng, các chương trình như Fulbright đóng vai trò quan trọng trong chính sách đối ngoại của Hoa Kỳ”.

Bên cạnh đó, việc hợp tác nâng cao chất lượng giáo dục đại học của Việt Nam thông qua các chương trình liên kết, chương trình tiên tiến còn giúp Hoa Kỳ có cơ hội khai thác nguồn nhân lực chất lượng cao, đạt hiệu quả tích cực trong việc mở rộng thị trường đầu tư tại Việt Nam đặc biệt trên lĩnh vực công nghệ, kỹ thuật. Chú trọng đầu tư phát triển nguồn nhân lực có tiềm năng như sinh viên Việt Nam, các tập đoàn, doanh nghiệp Hoa Kỳ như Intel, Pearson, Siemens... sẽ có cơ hội phát triển tại thị trường lao động chất lượng cao, chính là đầu ra của quá trình đầu tư vào các chương trình giáo dục đại học tiên tiến.

Thứ tư là sự nỗ lực trong hợp tác giáo dục đại học giữa Việt Nam và Hoa Kỳ từ trước khi bình thường hóa quan hệ ngoại giao hai nước, đặc biệt sự đóng góp tích cực của Chương trình giảng dạy kinh tế Fulbright đã góp phần nâng cao hơn nữa sự hợp tác trong lĩnh vực 
giáo dục đại học giữa hai quốc gia lên một tầm cao mới, đó là quyết định thành lập trường Đại học Fulbright tại Việt Nam. Từ lâu, Chính phủ và các nhà hoạt động giáo dục Việt Nam đã mong muốn xây dựng một trường đại học chất lượng quốc tế cũng như đem lại cơ hội học tập trong một môi trường chất lượng cao cho cộng đồng học sinh, sinh viên trong nước, đặc biệt là những người không có cơ hội du học nước ngoài bởi không đủ khả năng chi trả kinh phí, thì việc thành lập trường Đại học Fulbright chính là cánh cửa mở ra cơ hội cho người học Việt Nam, cũng như góp phần nâng cao chất lượng giáo dục đại học Việt Nam. Đây sẽ là trường đại học tư thục không lợi nhuận đầu tiên của Việt Nam, mang tính chất tự trị và chỉ thu 50\% mức học phí nhằm hỗ trợ tối đa cho sinh viên Việt Nam. Theo Công văn 821/TTgKGVX ngày 3/6/2014, Thủ tướng Chính phủ Nguyễn Tấn Dũng đã đồng ý chủ trương đầu tư Dự án Trường Đại học Fulbright Việt Nam (Fulbright University Vietnam - FUV). Cùng năm đó, trong quyết định phân bổ ngân sách của Quốc hội Hoa Kỳ và Luật Ngân sách được Tổng thống Obama phê duyệt thì ngân sách đầu tiên là dành cho trường Đại học Fulbright. Hai quyết định cho thấy sự quan tâm của hai nước dành cho lĩnh vực hợp tác giáo dục ngày càng phát triển này.

Thứ năm là các hoạt động hợp tác giáo dục đại học có những đóng góp không hề nhỏ trong quan hệ giữa Việt Nam và Hoa Kỳ. Chương trình Fulbright bắt đầu tại Việt Nam từ năm 1992 là một trong những bước đi quan trọng giúp Việt Nam và Hoa Kỳ nhanh chóng đi đến bình thường hóa quan hệ ngoại giao giữa hai nước. Quan hệ Việt Nam - Hoa Kỳ là một mối quan hệ đặc biệt, nhận được sự quan tâm, ưu tiên trong chính sách đối ngoại của cả hai bên, có thể nhận thấy trên lĩnh vực giáo dục là sự ra đời của Quỹ giáo dục Việt Nam VEF, đây là một chương trình đặc biệt, duy nhất mà Chính phủ Hoa Kỳ dành cho Việt Nam, nhằm hỗ trợ Việt Nam phát triển tiềm năng trong các ngành về khoa học, kỹ thuật, y tế. Bên cạnh đó có thể thấy hợp tác trong lĩnh vực giáo dục đại học là một trong những phương tiện giúp tạo dựng lòng tin, sự hiểu biết lẫn nhau, góp phần thúc đẩy quan hệ tích cực giữa hai nước. Mỗi sinh viên, giảng viên Việt Nam hay Hoa Kỳ tham gia vào chương trình trao đổi giáo dục đại học giữa hai nước đều trở thành một đại sứ thân thiện, góp phần xây dựng hình ảnh của quốc gia mình trong lòng nhân dân đất nước đối tác. Trong chuyến thăm Hoa Kỳ của Chủ tịch nước Trương Tấn Sang vào tháng 7 năm 2013, trò chuyện với Tổng thống Hoa Kỳ Barack Obama tại Nhà Trắng, hai nhà lãnh đạo ghi nhận vai trò của giáo dục trong quan hệ giữa hai nước từ trước đến nay, ghi nhận sự thành công của các chương trình trao đổi và các sáng kiến giáo dục, nổi bật là chương trình Fulbright và chương trình HEEAP. Chủ tịch Trương Tấn Sang và Tổng thống Barack Obama đồng ý rằng sự hợp tác chặt chẽ về giáo dục và đào tạo là những yếu tố quan trọng cho giai đoạn tiếp theo của mối quan hệ. 


\subsubsection{Một số hạn chế trong hoạt động họp tác giáo dục đại học giữa Việt Nam -}

\section{Hoa Kỳ}

Mặc dù hơn 20 năm hợp tác về lĩnh vực giáo dục đại học giữa Việt Nam và Hoa Kỳ đạt được nhiều kết quả khả quan thì vẫn còn một số hạn chế mà chúng ta cần xem xét để có thể tăng cường hợp tác và đạt được hiệu quả tối ưu từ những hoạt động hợp tác này.

Thứ nhất đó là sự hạn chế của Việt Nam trong quá trình tham gia vào hoạt động hợp tác trên lĩnh vực giáo dục đại học với Hoa Kỳ. Có thể thấy tiềm lực của Việt Nam về nền tảng nói chung và lĩnh vực giáo dục nói riêng còn non trẻ, so với nền giáo dục lớn mạnh lâu đời của Hoa Kỳ. Do đó trong quá trình hợp tác với Hoa Kỳ, các hoạt động trao đổi hầu hết diễn ra một chiều từ phía Hoa Kỳ. Tuy nhiên, Việt Nam vẫn luôn nỗ lực thể hiện vai trò tích cực của mình, khuyến khích các thành phần tham gia vào hoạt động trao đổi, cũng như dành sự chào đón nồng nhiệt đối với phía Hoa Kỳ tham gia hoạt động trao đổi giáo dục đại học với Việt Nam.

Cũng bởi những điều kiện về giáo dục, cơ sở vật chất chưa cao, nên Việt Nam còn hạn chế trong việc tiếp nhận những chuyển giao tri thức, tận dụng hiệu quả thành tựu giáo dục đại học phát triển của Hoa Kỳ. Đầu tiên là rào cản về ngôn ngữ, dù là ngoại ngữ phổ biến và được đưa vào chương trình học bắt buộc, nhưng phần lớn sinh viên, thậm chí là giảng viên Việt Nam chưa đạt được kĩ năng sử dụng tiếng Anh cần thiết để có thể tiếp thu các chương trình trao đổi cũng như liên kết giáo dục của Hoa Kỳ, do đó dù phía Hoa Kỳ sẵn sàng đầu tư hỗ trợ cho sinh viên, giảng viên Việt Nam theo học tại Hoa Kỳ nhưng trình độ tiếng Anh không đáp ứng có thể đã ngăn cản sự tiếp cận với nền giáo dục tiên tiến hiện đại. Bên cạnh đó, nền tảng giáo dục của Việt Nam còn nặng về lý thuyết, thiếu kĩ năng thực hành chuyên môn cũng như các kĩ năng mềm khác, do đó các sinh viên, giảng viên của Việt Nam khi du học tại Hoa Kỳ có thể gặp khó khăn trong việc tiếp thu phong cách giảng dạy, tận dụng hiệu quả những kiến thức học được. Đồng thời khi trở về Việt Nam, họ khó có thể truyền tải hết các kĩ năng thực hành cũng như kĩ năng mềm, một phần bởi học sinh, sinh viên Việt Nam đã quen với cách học đề cao lý thuyết, một phần do chưa đủ cơ sở vật chất trong giảng dạy ví dụ như các thiết bị, phòng thí nghiệm. Theo khảo sát điều tra của Tập đoàn Intel khi quyết định mở nhà máy tại Việt Nam, trong số 2000 sinh viên tốt nghiệp ngành kỹ thuật, chỉ có 90 người đạt trình độ tiếng Anh cần thiết và trong đó chỉ 40 người sử dụng các kĩ năng tiếng Anh một cách thành thạo để có thể nhận vào làm việc, đồng thời hầu hết sinh viên chưa được giáo dục những kỹ năng nghề nghiệp cơ bản. Những khó khăn về nền tảng giáo dục như kiến thức thực hành và trình độ tiếng Anh phần nào cản trở việc tiếp thu nền giáo dục tiên tiến với ý định tích cực tăng số lượng sinh viên được học chương trình bậc cao hơn ở Hoa Kỳ. 
Các thủ tục, hành lang pháp lý ở Việt Nam dù luôn cố gắng đơn giản hóa, song đối với các nhà đầu tư nước ngoài đôi khi vẫn còn phức tạp và là trở ngại, trong lĩnh vực hợp tác giáo dục đại học với Hoa Kỳ, đó có thể là những khó khăn trong việc xin visa cho các giáo sư, chuyên gia Hoa Kỳ sang giảng dạy tại Việt Nam hay các trường đại học của Hoa Kỳ muốn đầu tư, mở rộng liên kết tại các trường đại học của Việt Nam cần trải qua các quy trình tương đối phức tạp, điều này đôi khi ngăn cản sự phát triển của các hoạt động hợp tác giữa hai nước. Cùng với đó, trong giai đoạn trước thế kỷ XXI, do mới bắt đầu với các chương trình trao đổi giáo dục do đó Việt Nam chưa có đủ các cơ sở luật pháp, quy định về các chương trình hợp tác đào tạo, phần nào tạo ra một số sơ hở trong các chương trình hợp tác, đặc biệt là với các trường dù là của nước ngoài nhưng không đạt chất lượng, đồng thời thiếu quy định về công nhận bằng cấp, gây thiệt thòi cho người tham gia.

Thứ hai, tuy rằng Hoa Kỳ là một quốc gia phát triển với rất nhiều trường đại học danh giá hàng đầu thế giới nhưng không phải trường đại học nào của Hoa Kỳ cũng đạt được chất lượng này. Đồng thời bản thân nhiều trường đại học ở Hoa Kỳ, hay thậm chí một số nhà hoạt động trong lĩnh vực giáo dục của Hoa Kỳ chưa thực sự đạt trình độ cao, nhìn nhận Việt Nam như một đất nước nhỏ, kém phát triển do đó tạo ra những chương trình hợp tác không hiệu quả, hoặc đưa ra những khuyến nghị trên quan điểm hẹp, nặng tính chính trị của họ. Hay một số trường đại học Hoa Kỳ được đánh giá chưa thực sự hiệu quả (Koblitz, 2017). Do đó đây là một thách thức với Việt Nam trong việc lựa chọn đối tác thích hợp, nhằm đảm bảo chất lượng đào tạo nhân lực, đặc biệt trong các lĩnh vực khoa học - nền tảng của nền kinh tế tri thức mà Việt Nam hướng tới.

Thứ ba là hạn chế trong các lĩnh vực chuyên ngành mà các chương trình hợp tác, chương trình liên kết giữa các trường đại học của Việt Nam và Hoa Kỳ. Các lĩnh vực hợp tác trước đó chủ yếu là tài chính, thương mại và quản trị, trong khi đó Việt Nam có rất nhiều nhu cầu về các ngành quan trọng khác như khoa học, công nghệ, môi trường,... nhằm phát triển Việt Nam trên nhiều khía cạnh đa dạng hơn.

\subsection{Một số kiến nghị góp phần thúc đẩy quan hệ hợp tác Việt Nam - Hoa Kỳ}

\section{trong lĩnh vực giáo dục đại học}

Từ những thành tựu và hạn chế trong hoạt động hợp tác giáo dục đại học giữa Việt Nam và Hoa Kỳ nêu trên, tác giả đưa ra một số kiến nghị đối với Việt Nam nhằm thực hiện hiệu quả các chương trình hợp tác này cũng như thúc đẩy nhiều hoạt động hợp tác hơn nữa giữa hai quốc gia trong tương lai:

Một là, xây dựng hệ thống pháp luật một cách đầy đủ, rõ ràng về việc hợp tác trong lĩnh vực giáo dục đại học với nước ngoài ngoài, cụ thể trong các chương trình trao đổi, xây dựng chương trình liên kết tại đại học của Việt Nam nhằm kiểm soát cũng như phát triển một 
cách thích hợp và hiệu quả các chương trình hợp tác. Đồng thời đơn giản hóa các quy trình, thủ tục nhưng vẫn đảm bảo đúng pháp luật nhằm tạo điều kiện cho các giáo sư, chuyên gia giáo dục đến hỗ trợ tại các cơ sở giáo dục đại học của Việt Nam và thúc đẩy sự đầu tư của các quốc gia nước ngoài như Hoa Kỳ trong việc mở rộng các chương trình liên kết trong lĩnh vực hợp tác giáo dục đại học.

Hai là, chú trọng nâng cao trình độ tiếng Anh cho sinh viên và cả những giảng viên đại học, không chỉ cần thiết đối với những thành phần tham gia trực tiếp vào các chương trình hợp tác giáo dục đại học với Hoa Kỳ, đây còn là kĩ năng cần thiết để hợp tác, giao lưu trên lĩnh vực giáo dục cũng như các hoạt động hợp tác kinh tế, xã hội đối với Hoa Kỳ và cả các quốc gia khác, khi mà tiếng Anh là ngôn ngữ quốc tế, ngôn ngữ cơ bản để tiếp cận được nhiều nguồn thông tin, kiến thức từ thế giới. Làm chủ được trình độ tiếng Anh, sinh viên và các đối tượng khác có nhiều cơ hội để tham gia vào các chương trình trao đổi, hợp tác giáo dục đại học với những nền giáo dục đẳng cấp thế giới như Hoa Kỳ, cũng như có thể tiếp thu một cách hiệu quả nhất những kiến thức được học trong quá trình tham gia chương trình. Để nâng cao trình độ tiếng Anh đòi hỏi sự tích cực, chủ động của bản thân người học, đồng thời cần sự hỗ trợ của các chương trình học hiệu quả, ứng dụng cao, chính sách từ các cơ quan Chính phủ trong việc đầu tư nâng cao trình độ tiếng Anh cho số đông người học.

Ba là phát triển nền tảng giáo dục đại học tại Việt Nam, bằng cách nâng cao năng lực của các giảng viên, các nhà quản lý giáo dục, học hỏi thông qua các chương trình trao đổi với các nước thành công trong giáo dục đại học mà Hoa Kỳ là một ví dụ điển hình, thông qua các chương trình liên kết, chuyển giao chương trình giáo dục đại học của các trường đại học nước ngoài với đại học của Việt Nam, và đặc biệt là ở lĩnh vực nghiên cứu-nơi tạo ra nền tảng tri thức cần thiết. Điều này sẽ giúp giáo dục Việt Nam phát triển được hướng đi riêng, có khả năng đào tạo, xây dựng một lớp kế cận có khả năng tiếp cận với các kĩ năng, phương pháp mới trong thời đại của dữ liệu, phương pháp xử lí dữ liệu và điện toán (La \& Vuong, 2019). Nâng cao nền tảng giáo dục đại học sẽ giúp cho các sinh viên, giảng viên học bậc học cao hơn theo các chương trình đào tạo của Hoa Kỳ một cách hiệu quả, đồng thời giúp Việt Nam tiến gần hơn tới mục tiêu đạt tiêu chuẩn quốc tế về chất lượng giáo dục đại học.

Bốn là đầu tư cho chương trình giáo dục đại học, dùng ngân sách một cách hợp lý để nâng cao trình độ tiếng Anh cũng như chất lượng giáo dục đại học bằng cách mời các chuyên gia có trình độ từ các nền giáo dục đại học phát triển, đầu tư nâng cao cơ sở vật chất nhằm đáp ứng mô phỏng thực tế các bài giảng, nhất là những bài giảng mang tính thực hành cao từ chương trình đào tạo của Hoa Kỳ, đồng thời tạo cơ hội cho sinh viên áp dụng các kiến thức lý thuyết được học vào thực hành. Bên cạnh đó, cần có sự đầu tư vào bộ phận kiểm định chất lượng giáo dục đại học nhằm đánh giá hiện trạng của chương trình giáo dục đại học Việt 
Nam, đánh giá các trường đại học từ Hoa Kỳ để chọn đối tác phù hợp với nhu cầu hợp tác của mình cũng như đánh giá tình hình, hiệu quả hợp tác của các trường đại học Việt Nam với các đại học của Hoa Kỳ.

Năm là, khuyến khích tăng cường các chương trình liên kết, chương trình đào tạo chất lượng Hoa Kỳ tại các trường đại học ở Việt Nam nhằm tạo điều kiện cho nhiều sinh viên, giảng viên không có cơ hội du học tiếp cận với mô hình giáo dục tiên tiến hơn. Điều này vừa giúp giảm chi phí, vừa hạn chế được tình trạng chảy máu chất xám không mong muốn, đồng thời phát triển được chính các chương trình giáo dục đại học ngay tại Việt Nam. Không chỉ giúp Việt Nam nâng cao năng lực trong đào tạo giáo dục đại học mà còn thu hút thêm nhiều sinh viên nước ngoài du học tại Việt Nam, cũng như tạo thế cân bằng, trao đổi mang tính hai chiều trong hợp tác với các nước phát triển như Hoa Kỳ. 


\section{KẾT LUẬN}

Quan hệ hợp tác Việt Nam - Hoa Kỳ trong lĩnh vực giáo dục đại học từ năm 1992 đến năm 2015 nhìn chung ngày càng có sự phát triển đa dạng dưới nhiều hình thức, khẳng định vai trò của hợp tác giáo dục đại học trong sự phát triển quan hệ đối ngoại của hai quốc gia, đặc biệt từ khi bình thường hóa quan hệ ngoại giao và ngày càng có các bước tiến quan trọng, dấu mốc đặc biệt là hình thành quan hệ đối tác toàn diện vào năm 2013. Các hoạt động hợp tác trong lĩnh vực giáo dục đại học đã đem lại nhiều thành tựu to lớn cho cả Việt Nam và Hoa Kỳ. Với Việt Nam, đó là cơ hội tiếp cận với nền giáo dục tiên tiến hàng đầu thế giới, cơ hội học hỏi để phát triển nền giáo dục đại học của mình, phục vụ cho nhu cầu nâng cao chất lượng nguồn nhân lực, phát triển nền kinh tế tri thức mà nền tảng chính là các chương trình giáo dục đại học và những thanh niên có vai trò lãnh đạo trong tương lai của nước nhà. Đối với Hoa Kỳ, hoạt động hợp tác giáo dục đại học là một trong những phương tiện để thực hiện chính sách đối ngoại thông minh, tận dụng sức mạnh mềm để tăng cường hiệu quả hoạt động đối ngoại công chúng, dành được niềm tin và sự hiểu biết của nhân dân thế giới đối với Hoa Kỳ. Đối với cả hai nước, hoạt động hợp tác giáo dục đại học góp phần giúp quan hệ ngoại giao gắn bó hơn, xây dựng niềm tin và sự hiểu biết lẫn nhau hơn. Bên cạnh đó, còn một số hạn chế cần khắc phục trong hoạt động hợp tác trong lĩnh vực giáo dục đại học giữa Việt Nam và Hoa Kỳ. Nhưng đó chính là những bài học cho hai nước để tiếp tục cố gắng trong tương lai, hoàn thiện các hình thức hợp tác giáo dục đại học, giữ vững và nâng cao vị trí ưu tiên lĩnh vực giáo dục đại học trong quan hệ của hai nước. 


\section{REFERENCES}

Abuza, Z. (1996). The politics of educational diplomacy in Vietnam: Educational exchanges under Doi Moi. Asian Survey, 36(6), 618-631. DOI: 10.2307/2645795.

Barnett, R. (1992). The idea of quality: Voicing the educational. Higher Education Quarterly, 46(1), 5-7.

Bộ Giáo dục và Đào tạo. (2008). Đề án Đào tạo theo chưong trình tiên tiến tại một số truờng đại học của Việt Nam giai đoạn 2008-2015. Hà Nội. Retrieve from http://vanban.chinhphu.vn/portal/page/portal/chinhphu/hethongvanban?class_id=1\&m $\underline{\text { ode }=\text { detail \&document } \mathrm{id}=86901}$

Chính phủ. (2000). Nghị định về hợp tác đầu tư với nước ngoài trong lĩnh vục khám chũa bệnh, giáo dục đào tạo, nghiên cứu khoa học. Hà Nội. Retrieved from http://vanban.chinhphu.vn/portal/page/portal/chinhphu/hethongvanban?class_id=1\&_p $\underline{\text { age }}=1 \&$ mode $=$ detail $\&$ document $\mathrm{id}=7313$

Chính phủ. (2001). Nghị định quy định về việc lập và hoạt động của các co sở văn hóa, giáo dục nước ngoài tại Việt Nam. Hà Nội.

Chính phủ. (2012). Nghị định quy định về hợp tác, đầu tu của nước ngoài trong lĩnh vục giáo duc. Hà Nội. Retrieved from http://vanban.chinhphu.vn/portal/page/portal/chinhphu/hethongvanban?class_id=1\&m ode $=$ detail\&document $\_$id $=163907$

Cục Hợp tác Quốc tế. (n.d.). Retrieved from http://vied.vn/vi/

Cull, J. N. (2008). Public diplomacy before Gullion: The evolution of a phrase. In P.M. Taylor \& N. Snow (Eds.), Routledge Handbook of Public Diplomacy (pp. 39-43). Abingdon, U. K.: Routledge.

Dao, M. H., \& Le, H. H. (2013). Sổ tay Thuật ngũu Quan hệ Quốc tế. Ho Chi Minh City: Khoa Quan hệ quốc tế - Đại học Khoa học Xã hội và Nhân văn.

Doan, V. D. (2015). Quản lý nhà nước về chất lượng giáo dục đại học (Doctoral dissertation, Học viện Hành chính Quốc gia, Hanoi).

Dong, X. T. (2016). Sự điều chỉnh chiến lược của các nước lớn đối với khu vực châu Á - Thái Bình Dương. Tạp chí Cộng sản. Retrieved from http://www.tapchicongsan.org.vn/Home/The-gioi-van-de-su-kien/2016/41547/Su-dieuchinh-chien-luoc-cua-cac-nuoc-lon-doi-voi-khu.aspx

Ha, K. N. (2016). Quan hệ Đối tác toàn diện Việt Nam - Hoa Kỳ sau 20 năm thiết lập quan hệ ngoại giao. Đầu tu online. Retrieved from https://baodautu.vn/quan-he-doi-tac-toandien-viet-nam---hoa-ky-sau-20-nam-thiet-lap-quan-he-ngoai-giao-d44946.html

Hoang, K. N. (2016). Giáo trình nhập môn quan hệ quốc tế. Hanoi: Đại học Quốc gia Hà Nội. Retrieved from http://repository.vnu.edu.vn/handle/VNU_123/58583.

Hoang, V. Q., \& Dung, T. T. (2009). The cultural dimensions of the Vietnamese private entrepreneurship. IUP Journal of Entrepreneurship Development, VI(3-4), 54-78.

Koblitz, N. (2017). Higher education: Is it wise for Vietnam to imitate the US?. VnExpress International. Retrieved from https://e.vnexpress.net/news/news/perspectives/highereducation-is-it-wise-for-vietnam-to-imitate-the-us-3562884.html. 
La, V. P., \& Vuong, Q. H. (2019). bayesvl: Visually Learning the Graphical Structure of Bayesian Networks and Performing MCMC with 'Stan'. The Comprehensive $R$ Archive Network $\quad(C R A N)$ : $\quad<$ https://cran.rproject.org/web/packages/bayesvl/index.html>; version 0.8.5 (May 24, 2019).

Marklein, B. M., \& Mai, V. T. (2016). U.S. Policy, Soft Power and Higher Education Reform in Vietnam. In Knowledge Journeys and Journeying Knowledge (pp. 125-142). Hanoi: The Gioi.

Mishra, S. (2007). Quality Assurance in Higher Education: An Introduction. Karnataka: Commonwealth of Learning \& National Assessment and Accreditation Council (NAAC). Retrieved from http://oasis.col.org/handle/11599/101

Nguyen, A. C. (2015). Quá trình bình thuoòng hóa và phát triển quan hệ Việt Nam - Hoa Kỳ (1976-2006). Hanoi: Đại học Quốc gia Hà Nội.

Nguyen, B. T. (2010). Quan hệ Việt Nam - Hoa Kỳ trên lĩnh vực văn hóa, giáo dục và xã hội từ năm 1995 đến nay (Doctoral dissertation, Đại học Khoa học Xã hội và Nhân văn, Hanoi)

Nguyen, T. A. (2009). The Internationalization of higher education in Vietnam: National policies and institutional implementation at Vietnam National University, Hanoi. Global COE Program, Global Institute for Asian Regional Integration, GIARI. Waseda University. Retrieved from http://www.waseda-giari.jp/sysimg/imgs/wp2008-E-21.pdf

Nguyen, T. T. (2015). Hợp tác giáo dục đại học giữa Việt Nam và Hoa Kỳ từ đầu thập niên 1990 đến nay. Châu Mỹ ngày nay (7), 9-15.

Nguyen, X. S. (2006). Chiến lược đối ngoại của các nước lớn và quan hệ với Việt Nam trong hai thập niên đầu thế kỷ XXI. Hanoi: Chính trị Quốc gia.

Nye, J. (2005). Soft Power: The Means To Success In World Politics. New York, NY: Public Affairs.

Pham, M. S. (2016). Đối ngoại công chúng: Mô hình hoạt động của một số nước lớn trên thế giới và đề xuất đối với Việt Nam. Hanoi: Lý luận Chính trị.

QN. (2016). Đào tạo theo chương trình tiên tiến có tác động tích cực đến các hoạt động của trường đại học. Báo điện tử Nhân dân. Retrieved from http://www.nhandan.com.vn/giaoduc/tin-tuc/item/31707502-dao-tao-theo-chuongtrinh-tien-tien-co-tac-dong-tich-cuc-den-cac-hoat-dong-cua-truong-dai-hoc.html.

Rhodes, H. T. F. (2001). The Creation of the Future: The Role of the American University. Ithaca, NY: Cornell University Press.

Robbins, M. E. (2013). From enemies to friends: the improvement of U.S. - Vietnam relations through educational exchanges, 1992-2013 (Master's thesis, Georgetown University, Washington, D.C.). Retrieved from https://repository.library.georgetown.edu/bitstream/handle/10822/55833

The Hubert H. Humphrey Fellowship Program. (n.d.). Retrieved from https://www.humphreyfellowship.org/about-program

U.S. - Vietnam Education Task Force (2009). Final Report. Retrieved from https://photos.state.gov/libraries/vietnam/8621/pdf-forms/ETFReport-Sept09.pdf.

U.S. Congress (1961). Mutual Educational and Cultural Exchange Act of 1961.

U.S. Congress (2000). Vietnam Education Foundation Act of 2000. Retrieved from https://www.congress.gov/106/bills/hr5581/BILLS-106hr5581ih.pdf. 
U.S. Embassy \& Consulate in Vietnam. (n.d.). Retrieved from Retrieved from https://vn.usembassy.gov/vi/education-culture-vi/edu-exchange-vi/

U.S. Embassy \& Consulate in Vietnam. (n.d.). Retrieved from Retrieved from https://vn.usembassy.gov/education-culture/fulbright-program-vietnam/us-scholarprogram/

UNESCO. (1998). World declaration on higher education for the twenty-first century vision and action, World Conference on Higher Education, UNESCO Headquarters in Paris. Paris: UNESCO.

University Archives \& Historical Collections of Michigan State University (n.d.). Retrieved from Vietnam Project Archives. Retrieved from http://archives.msu.edu/collections/vietnam_msug.php.

Vu, L. T. H. (2009). Ngoại giao công chúng trong thế kỷ 21. Nghiên cứu Quốc tế (76). Retrieved from http://nghiencuuquocte.org/2014/06/18/ngoai-giao-cong-chung-trongthe-ky-21/

Vuong, Q. H. (2018). The (ir)rational consideration of the cost of science in transition economies. Nature Human Behaviour, 2(1), 5, DOI: 10.1038/s41562-017-0281-4.

Vuong, Q. H., La, V. P., Vuong, T. T., Nguyen, V. H., Ho, M. T., Nguyen, T. H. K., Bui, Q. K., \& Ho, M. T.. (2018). Cultural additivity: Behavioural insights from the interaction of Confucianism, Buddhism, and Taoism in folktales. Palgrave Communications, 4, 143. DOI: 10.1057/s41599-018-0189-2. 